\title{
A Science-Based Sector in the Making: the formation of biotechnology sector in two
} regions

\author{
Antonios Angelakis $^{{ }^{*}}$ Kostas Galanakis $^{\mathrm{b}}$ \\ annovation analyst at The Small Enterprises' Institute - The Hellenic Confederation of Professionals, \\ Craftsmen \& Merchants (IME GSEVEE), Aristotelous 46, 10433, Athens, Greece. \\ angelakis@imegsevee.gr \\ ${ }^{b}$ Principal Lecturer, Nottingham Business School, Nottingham Trent University, \\ Burton Street, NG1 4BU, UK \\ kostas.galanakis@ntu.ac.uk
}

*Corresponding author. 


\title{
A Science-Based Sector in the Making: the formation of biotechnology sector in two
}

\section{regions}

\begin{abstract}
This paper analyses two case studies, Skåne-Blekinge in Sweden and the Southern-Eastern region in Ireland, to examine different current development paths for the biotechnology sector. The aim is to codify the process, identifying actions and priorities towards these paths. The national innovation systems theory provides the theoretical framework that guided a series of interviews in the two regions. The findings demonstrate that the sustainable development of a science-based sector does not depend on the original priorities or directions, but rather on the level of consistency of those policies and their continuous evolution towards a complete systemic value generation system.
\end{abstract}

KEY WORDS: Value generation systems; Innovation Policy; Biotechnology; Regional innovation systems; Case study

\section{Introduction}

The global biotechnology industry has exhibited high growth rates in terms of research achievements, sales and employment (GÖRANSSON and PÅLSSON, 2011), although its effect on regional economic growth has been questioned (PISANO, 2006). As a sector, biotechnology has been dependent on, and had a major impact on, a range of other sectors such as the pharmaceutical sector and the agro-food sector (HOPKINS et al., 2007). The biotechnology sector is distinguished from other technology-intensive sectors due to the complexity of its activities, the scale of required investments, the barriers to entry and the 
high thresholds on learning capabilities (PISANO, 2006). To deal with these characteristics, focused policies have been implemented with an emphasis on the development of knowledge infrastructures and the formulation of institutions to foster technology transfer and innovation financing (SENKER et al., 2000). Moreover, several policy measures have included the enhancement of collaboration between academia and industry and the formulation of production agglomerations through the attraction of foreign investment in large plants by multinational companies. However, these characteristics of the sector demand further institutional conditions which can address uncertainty, constant knowledge advancement and high-risk-financing (BANERJEE and COLE, 2012).

Innovation systems theory provides an analytical framework to formulate innovation, science and technology policies. This theory is based on the idea that innovation is produced through an interactive process which includes several different actors and processes (GALANAKIS, 2006). The theory relates the policy of innovation players to the ability of firms to innovate, which in turn affects the wealth of a nation (EDQUIST, 1997). As this is related to national competitiveness and performance, studies have been initiated within different disciplines, ranging from urban economics to economic geography, institutional and evolutionary economics and policy analysis (CARLSSON et al., 2002). The theory furthermore attempts to identify the social and economic impact of the process that creates innovation and the impact on the actors, the interrelation between the actors across a nation and the mechanisms affecting and enhancing knowledge generation and knowledge exploitation (ASHEIM et al., 2011). Furthermore, several studies highlight the need for innovation policies to deploy mechanisms for tailoring a system's functions to: national characteristics (LUNDVALL, 1992; NELSON, 1993); regional innovation system characteristics (TÖDTLING and TRIPPL, 2005); and, sectoral or technological innovation characteristics, focusing on the development of a specific technology or sector. 
The objective of this paper is to examine different current development paths for the biotechnology sector in two distinctive European regions, under the systems of innovation theory. The aim is to codify the development process, comparing actions and priorities. This codification may support policy-makers in the design of specific measures and programmes in the sector, according to the special conditions and priorities in their region.

The analysis is applied in two European regions with comparable size and level of economic development ${ }^{1}$ - Skåne-Blekinge in Sweden and the Southern-Eastern region of Ireland. The two regions have been selected as they represent two distinctive schools of thought for development. Skåne-Blekinge, is considered a highly developed area in terms of its research capability, constituting part of the broader area of Medicon Valley (with Copenhagen, Denmark), and is one of the top-five biotechnology research hot-spots in Europe (www.fiercebiotech.com) . In Skåne-Blekinge, the life sciences sector involves around 7,000 individuals and comprises $15 \%$ of the total Swedish production volume (value added) with the major fields being pharmaceuticals, biotechnology and medical technology (HENNING et al., 2010). On the other hand, in the Southern-Eastern region most of the multinational companies in the sector had already invested in the region by the 1980s, as they were attracted by the incentives provided by the Central Government through the Industrial Development Agency (IDA). These incentives included grants, tax incentives, co-funding facilities and R\&D incentives. As a result, pharmaceutical and bio-pharmaceutical industry exports reached $€ 50$ billion in 2010, while pharmaceutical and chemical products accounted for over $50 \%$ of Irish exports. It is estimated that these sectors employ over 24,300 people nationally (PHARMACHEMICAL IRELAND, 2011). Already by the middle of 2000s, the biotechnology sector employs more than 4,000 people in Ireland, with most of them based in the Southern-Eastern region (INTERTRADEIRELAND, 2003). 
The paper is structured as follows: Section 2 reviews the theory connected to innovation systems and knowledge flow partners at national, regional or sectoral level to demonstrate the factors that are often used to support policy formation. Section 3 describes the methodology used in the analysis of the two case studies. Section 4 provides an analysis of the two distinctive regional innovation systems, from the perspective of the policy, the institutional formation and the business exploitation environment. Section 5 provides a comparative discussion of the two cases with respect to lessons related to the structure, functions and performance of the systems, which are codified under a conceptual framework. Finally, the concluding section addresses the objective and provides an overall view highlighting the complete picture of the development of a science based sector such as biotechnology.

\section{Systemic components and knowledge patterns for developing a science-based sector}

In principle, innovation systems strategies involve a set of initiatives aiming to enhance the capacity of companies to introduce knowledge assets and produce new products or services, usually by encouraging collaboration between knowledge users and producers (NAUWELAERS et al., 2008). These policy initiatives may be codified to five important subsystems (LUNDVALL and BORRAS, 2005), affecting the performance of innovation activity: the public sector as policy designer and regulator; the knowledge generation subsystem; the knowledge exploitation sub-system; the physical set-up of supporting mechanisms and institutions, and the institutional set-up of the financial sector. A systems-oriented innovation policy, however, attempts to support and often to control both the components and the links, which are crucial for the functioning of a system (EDQUIST, 2011). Such policies aim to tackle embedded institutional and functional barriers and to accelerate knowledge exploration, diffusion and exploitation (TER WAL and BOSCHMA, 2011). 


\subsection{Systemic Components}

The knowledge generation sub-system includes universities; public and private research organisations; and knowledge transfer and research funding institutions (ASHEIM and COENEN, 2005). The knowledge generation process is enhanced by: intra-national (e.g. the European Union Framework Programmes), national and regional science and innovation policies; general knowledge infrastructures (soft infrastructure); the funding of basic and applied research activities; and innovation-supporting institutions, such as science and technology parks and technology and knowledge networks.

The impact of the knowledge generation sub-system, depends on the ability of the system to apply and exploit these results. Therefore, novel results are introduced, producing innovative products and services or business models; i.e. firms that generate appropriate value chains and trading relations. This part of the system is affected by the way in which firms are organized, cooperate and interact. Biotechnology companies have used several business models ${ }^{2}$ to develop their activities and to deliver value, based on differentiated capabilities, value chain position and specialisation. However, the density of research, the scale of investment that is required and the complexity of manufacturing activities have encouraged the emergence of alternative business models, such as the "technology platforms" and cluster generation (CASPER, 2007), differentiating the processes of value creation and sustainability paths.

In cases where knowledge, complexity and uncertainty are intrinsic features creating high capital costs, the role of innovation-supporting institutions and innovation systems' activity seems to be particularly significant. Unsurprisingly, due to the high technological uncertainty and organisational complexity that characterise the biotechnology sector, its growth increasingly requires system-oriented innovation supporting mechanisms, oriented to knowledge diffusion and alternative funding. Therefore, innovation-supporting institutions, 
providing common infrastructure (e.g. research, testing and prototyping labs), novel knowledge transfer, and networking mechanisms, which specialise in and prioritise biotechnology, are prerequisites for the sector's growth (PISANO, 2006).

Finally, the institutional set-up of the financial sector plays a crucial role in the sustainability of the system even though R\&D active firms finance this activity primarily out of cash flow (HALL, 2002) with external finance as a secondary source. External R\&D investment has a higher level of impact when it is bank-based (e.g. venture capitalists or investment banks) rather than market-based - i.e. stock market capitalisation. This relates to the information asymmetry between the firm and the potential investors. The banking system, which shows maturity and understanding of the sectoral conditions, has the capacity to investigate the potential of such long term investments in greater depth. Furthermore, in many cases national systems have provisions for tax relief on $R \& D$ investment, matching funds or public guarantees for private $\mathrm{R} \& \mathrm{D}$ activities or internal investment for firms to gain operational efficiencies. These interventions may be summarised in three categories: grants, loans or government contracts; incentives and tax law provisions; and national or international research collaborations (RAHM et al., 2000).

The nature of the formation of the components of a science-based sector, such as biotechnology, gives rise to the first research question:

RQ1: What are the distinctive characteristics of a science-based regional innovation system that derive from the different formation path of its components?

\subsection{Knowledge flow patterns}

The growth of biotechnology, is affected by knowledge creation and diffusion patterns. Knowledge has been seen as an object and as an action (knowing), in which progress is made 
through active engagement with the world. This view broadens the distinction of knowledge between tacit and explicit to the importance of social capital, or network ties (ADLER and KWON, 2002) that provide access to resources. Knowledge generation and diffusion, yet, tends to be highly localised (MIGUÉLEZ AND MORENO, 2015) especially for sectors such as biotechnology, pharmaceuticals and chemicals, in contrast to electronics and information and communication technologies (ADAMS, 2002). BOTTAZZI and PERI (2003) for example demonstrate the locality of knowledge generation measuring the effect of doubling R\&D investment in a region compared to a neighbouring one. Their results $-80-90 \%$ increase of new ideas generation on the region where the investment took place in comparison to $2-3 \%$ in the neighbouring one - demonstrates the spatial effect, although others have found an existing but much lower importance (e.g. AUTANT-BERNARD and LESAGE, 2011).

The institutional factor and relevant incentives have been found to be determining factors for both generating and diffusing knowledge (AUTANT-BERNARD et al., 2013), thus highlighting the important role of innovation policies and priorities. Furthermore, diffusion is highly related to mobility of skilled employees (SINGH and AGRAWAL, 2011), the ability of a region (or a firm) to "anchor" the mobile skilled staff (LOWE and GERTLER, 2009) and to facilitate productive between knowledge creators and the industry.

Universities with their specificities and distinctive characteristics, occupy a central position in the generation of knowledge. Nevertheless, they are not naturally connected with industry and its priorities (AUTANT-BERNARD et al., 2013). This connection though - keeping the identity of each side - is considered as very important for knowledge-based economies (FORAY and MAIRESSE, 2002), as interactions benefiting researchers, institutions and the private sector. The inter-industry contacts and networks further stimulate the exchange of 
knowledge since knowledge generation is a collective activity among a variety of agents. BURT (1992) suggests that social relations and channels provide benefits in the forms of access, timing and referrals. Network ties provide the channels - or their absence creates a barrier - for information transmission, compensating for the absence of geographical proximity (GUAN, et al., 2015). The configuration of these ties - density, connectivity, stability over time, openness and hierarchy - affect the development of intellectual capital (ADLER and KWON, 2002).

Thus, the challenge is to initiate and sustain the collaboration between all the different agents and to implement a variety of mechanisms capturing and absorbing local and external knowledge (AUTANT-BERNARD, et al., 2013; MUKHERJI and SILBERMAN, 2013). In the case of biotechnology, GERTLER and LEVITTE (2005) suggested that highly planned knowledge networks that spread across nations play a significant role in innovation, breaking the trend of localised knowledge flows. However, they observed that this may take place during the later stages of the innovation process and not equally in the early developing stages. For regions in which biotechnology activity is still in an emerging stage activities are concentrated around regional public or private champions. However, even then, they search for knowledge and complementary skills from the international terrain on the basis of former international social and professional networks (VALE and CARVALHO, 2013).

Finally, the intensity of knowledge flows and commitment to innovation enhancing interactions between MNEs and domestic firms depends on the perceived advantage from both sides. Furthermore, the absorptive capacity of the domestic firms and the technology/productivity gap may be the drivers of knowledge adoption and flow as a result of foreign direct investments (CRESCENZIA, et al., 2015). Internationalised domestic firms 
have a lower potential to learn from MNEs or to perceive collaborations as beneficial as they usually tend to have higher productivity rates already and are more likely to be direct competitors in international markets (CRESCENZIA, et al., 2015).

These distinctive patterns of knowledge flow give rise to the second research question: RQ2: How does the formation path of a science-based regional innovation system differentiate its ability to generate, diffuse and exploit knowledge and skills?

\section{Methodology}

This paper follows an abductive methodology (REICHERTZ, 2007). The study analyses two empirical case-studies (YIN, 1994) and codifies the distinctive processes of the formation of the two systems. Two NUTS II regions have been used to collect data: the Skåne-Blekinge region of southern Sweden and the Southern-Eastern region of Ireland. Over the last decade the case study approach has been used extensively in a wide range of academic disciplines (COLLIS and HUSSEY, 2003) such as, economics, business and innovation studies, and public policy.

The data collection based on the analysis of a variety of documents, including academic journal articles, policy reports (for example from FORFAS, the European Commission, OECD and VINNOVA), company reports and relevant websites (for example, those of the Industrial Development Agency or Invest in Skåne). As a second step, twenty in-depth interviews, based on semi-structured questionnaires, were conducted during two research visits to the two regions (Appendix A, Table A.1). The interview questions investigated perceptions related to the impact of innovation policies; the evolution of regional innovation systems; and, the activity of biotechnology companies. The interviews were conducted with 
staff at policy-making institutions, regional actors and mechanisms, business associations, technology transfer offices in the largest universities, business development organisations, science parks and incubators. The interviews were conducted anonymously and the results summarised in a codification for each case (Complete transcript of the interviews are available at ANGELAKIS, 2011). Finally, the knowledge application and exploitation subsystems have been explored through research on the company websites. The validity of the information has been cross-checked with relevant official databases (e.g. Medicon Valley, IDA company database).

\section{The policy and institutional formation in the two regions}

In the Swedish case innovation policy was a central policy issue as early as the 1940's (the Swedish Technical Research Council - TFR was launched in 1942 and replaced in 1968 by the Swedish National Board for Technical Development - STU). Industrial policy, during the 1980s, focused mainly on restructuring key industrial sectors and included in the policy mix a first wave of funding aiming at the establishment of research infrastructure. During the 1990s, activities and funding gradually shifted toward the promotion of applied research, the enhancement of partnerships and collaborative programmes between industry and public research institutions and universities. This aimed to encourage the exploitation of knowledge and networking between academics and the private sector. These directions became central to the national agenda in the early 1990s' with the establishment of Swedish National Board for Technical and Industrial development (NUTEK) - merging the STU, the Agency for Industrial Development (Industriverket) and the Energy Agency - and its successor, the Swedish Governmental Agency for Innovation Systems (VINNOVA), in 2001. 
Innovation policy in Ireland highlights the gradual shift from the initial paradigm of economic protectionism (e.g. the Control of Manufacturers Act) to the introduction of measures to attract significant foreign direct investments (FDI) as early as the 1960s. Innovation policy became a crucial part of growth strategies during the following decades. The Science and Technology Act in 1987 constituted a major step in building Irish technology policy, by creating a framework for an enhanced research infrastructure and the need for a prosperous indigenous industry (HILLIARD and GREEN, 2005). The first policy in relation to biotechnology derived from that (the National Biotechnology Programme in 1987), promoting collaboration between industry and academia (SPRU, 2007). As a result BioResearch Ireland was formulated (later the Biotechnology Directorate of Enterprise Ireland). Nonetheless, by the middle of the 1990s, the performance of medium/large Irish-owned industry proved disappointing (see for example the Culiton Report, 1992). Although Ireland had received the highest level of FDI in Europe by almost every major MNE in the sector, the collaboration and exploitation of the rich knowledge-base of its universities ${ }^{3}$ was poor (HEWITTDUNDAS and ROPER, 2008). Therefore, the policy progressed, aiming at a more balanced strategy than the FDI-based growth path and an innovation agenda designed with the support of the EU structural funds and objectives that stated in the regionalisation agenda (IDA, 2011). The institutional and systemic characteristics of the two regions are summarised in Appendix B, Table B.1.

\subsection{The supportive components in the two regions}

The Swedish innovation policy paradigm is based on the application of "systemic instruments" on fostering forward-looking aspects of policies, especially though innovation policy planning coordinated by organizations such as VINNOVA. This direction derived directly from the "triple helix" concept, which was promoted by the European Union's policy framework and realised largely through VINNOVA's public-private collaborative schemes. 
These partnerships were driven by the knowledge capacity of Lund University ${ }^{4}$ (Appendix A, Table A.3) and the intermediate structures that developed around the University, for example IDEON (Appendix A, Table A.4).

These trends have been further intertwined with European public research, technology and innovation policies which no longer remain exclusively in the hands of national authorities but are supplemented by regional innovation policies or transnational programmes (KUHLMANN, 2001). Following these, Sweden attempted to distinguish innovation policy at regional level, by the creation of a 10-year initiative to form an elected regional government (COENEN, 2007). This reform included a shifting of responsibility for economic development at regional level, through the regional growth agreements (Regionala TillväxtAvtalen). The regional agreements and programmes were following national policies (e.g. the Regional Development Programme for Skåne 2009-2016), which were designed using "functional regions" instead of "territorial regions" (OECD, 2006). Functional regions used by VINNOVA in order to promote internationally competitive regional innovation systems (VINNOVA, 2007). The major benefit from the regional agreements was the increase of understanding across the national innovation actors ${ }^{5}$ of the role of science in economic growth and the identification of the so-called "third role" of universities. The policies followed eventually led to structural changes in the Swedish industry, improving manufacturing employment, productivity and intensified the activities in high-technology sectors (BITARD et al., 2008).

In the Southern-Eastern, the investment in knowledge infrastructure or in supporting mechanisms came later (initiated in the late 1990s) and were much more fragmented and limited in scale in comparison to Skåne-Blekinge. This fragmentation occurred as these facilities spread across the academic and research structures (Appendix A, Table A.5), limiting their ability to generate synergies and efficient networking. The emergence of Forfás 
(established in 1996) led to the formulation of an industrial plan, which reconfirmed biotechnology as a priority sector (FORFAS, 2011).

The same recognition stated by the Technology Foresight and put forward in 1997 by the Irish Council for Science, Technology and Innovation. In the same period, Enterprise Ireland (EI) launched the "Building Biotech Businesses" programme to support indigenous start-ups, encouraging the establishment of at least 40 biotechnology companies (SENKER et al., 2000). An important advantage for Ireland, in parallel to other incentives for established firms and institutions, was the nation's connection to the Anglophone world which attracts highly skilled personnel and researchers (HEWITT-DUNDAS and ROPER, 2008).

Research related investment was accelerated during the period 2000-2010. In 1998, HEA launched the Programme for Research in Third-Level Institutions (PRTLI), one of the largest funding programmes in the country, which was co-funded by the European Union Structural Funds and the European Regional Development Funds. PRTLI supported an extensive biotechnology research infrastructure. During the period 2000-2007 this investment averaged to $€ 22.4$ million annually (SPRU, 2007), specifically targeting the development of infrastructure and research activities for universities and technology institutes. In 2011, HEA provided $€ 131$ million for the development of the Trinity Biomedical Science Institute, indicating a concentration of funds on a select few national champions. Around the same period, the Technology Transfer Strengthening Initiative was created by EI in 2006 with a budget of $€ 30$ million, which still remains a major funding source for such mechanisms.

\subsection{The exploitation dimension in the two regions}

A significant difference between the two regions is the absence of MNEs in Skåne-Blekinge while in Southern-Eastern more than 20 MNEs are present and remain the major employer. In Skåne-Blekinge, the rise of new ventures benefited from the long-term research focus on the 
biotechnology sector, the collaboration initiatives and the funding mechanisms. It is estimated that in the broader Medicon Valley, the number of biotechnology firms exceeds 140. About half of these (68 firms) are start-up firms in Skåne-Blekinge. The trend accelerated after 2006 (Appendix B, Table B2), since when the total number of firms has doubled and university spin-offs tripled. From the 37 spin-offs in the region, operating after 2006, 35 originated from Lund University (LU), demonstrating the impact that it has had in the sector, while only a few emerged as spin-outs or subsidiaries of pharmaceutical companies ( 3 and 2 respectively).

The Southern-Eastern region in Ireland has seen a similar number of start-ups recently, with 67 biotechnology companies operating in the region since 2006 . However, only $40 \%$ of them are university spin-offs (Appendix B, Table B2). One in ten of the start-ups is a result of the Elan spin-out phenomenon ${ }^{6}$, which caused a significant exodus of professionals toward private spin-outs (CURRAN et al, 2011). A further 25\% are direct subsidiaries of MNEs. In both cases, the majority of the start-ups remain micro (with less than 10 employees) or small (between 10 and 50 employees) (Appendix B, Table B2). This is especially true in Skåne, where 7 out of 10 remain micro firms. University spin-offs in the Southern-Eastern have had a significantly larger impact on employment and together with the MNEs of the sector account for approximately $10 \%$ of total employment.

Regarding the sources of finance of the various start-ups, our research shows that $82 \%$ of the companies in Skåne-Blekinge secured investments by national or international private and public venture capital funds, or regional and sectoral ones (e.g. LU Bio) that are co-funded by European Union Programmes (Appendix B, Table B3). Their funding strategies follow a riskspread multi-partite approach, including founders, holding companies and venture capital participation. In Southern-Eastern, venture capital funds were initiated by the backing of Enterprise Ireland, which directly provided funding or guarantees for investment from 
international investment funds. Two thirds of their funding is directed toward spin-out activities which are considered more mature with a lower risk level, although their number is about half that of the spin-offs. MNE's subsidiaries in Southern-Eastern follow an investment pattern based on public offerings and partnerships, supported by IDA grants or facilities. This orientation, chosen by around $40 \%$ of the firms in Southern-Eastern, may lead these firms to under-invest in long-term $\mathrm{R} \& \mathrm{D}$ projects as shareholders in general tend to invest in more mature, lower risk projects that present a fast, profitable outcome. However, this type of investment in Skåne-Blekinge is much less frequent, with only $18 \%$ of firms taking this finance route. Appendix B, Table B.4 summarises the business environment in the two regions.

\subsection{Perceptions of innovation policy and structures in the two regions}

A major difference between Skåne-Blekinge and Southern-Eastern is the importance of local actors. In Skåne-Blekinge, many local actors took centre stage after the 1990s as the result of regional agreements. The distinction between functional and territorial regions partly limited the ability of the regional stakeholders to be the drivers of regional level policy. In SouthernEastern, in contrast, the national policy actors directed the activities throughout the whole period, spreading activity and funding across the several actors. Interviewees wondered however, whether these activities would be viable if support is withdrawn (Appendix B, Table B.5). Furthermore, they noted that innovation policy is often affected by the competing interests of several national actors ${ }^{7}$ with no actual consultation from the two newly formed regions - the Border Midland \& Western Region (B.M.W.) and the Southern and Eastern Region (S\&E). Furthermore, in the Southern-Eastern the interviewees questioned the consequences of the policy to attract MNEs. The Southern-Eastern, indeed, has attracted major MNEs through direct support in the sector (e.g. IDA business park support). The policy assumed, nevertheless, that $\mathrm{R} \& \mathrm{D}$ and the collaborations with the regional research institutions 
would have been led by the major MNEs that had invested productively in the region. This however, did not materialise and led to low R\&D activity of the industries or to only sporadic collaborations with universities and research institutions which proved unsustainable after the relevant programmes were completed. The interviewees pointed out that both indigenous and multinational biotechnology companies had received significant support by the IDA, in developing productive activities, requiring skilled employment that attracted international attention. Now, though, it is necessary to support organic growth in order to sustain their development. They raised the importance of increasing $R \& D$ as part of total investments in Southern-Eastern and stressed the evident need for still greater effort in the development of more local strategic collaborations. The interviewees, moreover, felt that despite occasional public-private R\&D collaborations with major firms (e.g. Pfizer, GSK, Eli Lilly) and the support of spin-offs from EI, the sponsored programmes had had limited impact. This was due to the low level of initial interest in knowledge exploitation by the academic community, the limited scale of R\&D capacity in the MNEs and the general underdeveloped area of seed capital support.

The limited seed capital support and reluctance from academics to engage in entrepreneurial activities was noted by the interviews in Skåne-Blekinge, too. In this case, though, they praised the importance of actors such as University holding companies to increase such awareness and the support mechanisms to start-ups providing them access to world class R\&D infrastructure ${ }^{8}$, allowing them to develop specialised intermediate products, treatments and therapies. Furthermore, they are able to provide specialised services to other firms through service contracts.

The size of the firms in the sector remains an impediment in both cases, raising issues related to the integration of productive activities, the scale of production and the ability to generate 
multiple product and service pipelines as a spread-risk strategy (FISKEN and RUTHERFORD, 2002). The interviewees, in both cases, stressed their perception of the dependency of spin-offs on national policy tools and universities' research activities because of their micro/small size. As ASHEIM and COENEN (2005) showed the size of a company is strongly associated with its origin. University spin-offs are usually small and frequently single-employee firms. This dependency however, was seen as a significant limitation in terms of the internationalisation of their activities and their potential to grow. Furthermore, the high degree of specialisation imposes three major challenges in both cases: a) sustainable value generation, $b$ ) the proximate market demand fluctuations and margins and $c$ ) the technological downgrading. These features create a business environment requiring a further evolving portfolio of localised priorities, policies and business models related to knowledge accumulation, technology improvement, networking and open innovation (CHESBROUGH, 2003). Our research in Skåne-Blekinge noted that despite the proximity of the region to the Copenhagen region, which creates a pulling agglomeration for large pharmaceutical and biotechnology companies, only about a third of the firms have an international presence, usually through the provision of specialised services to larger users. However, in SouthernEastern the interviewees underlined as beneficial the dependence of the start-ups on the MNEs that are based in the region, since they provide them with specialised services or licensed products, while one fifth specialise in diagnostics and bio-analytic services.

\section{Discussion}

The different policies and prioritisation in the two regions has created two distinctive systems. This distinction is due not to the nature of actors active nationally or regionally, but rather to the policy and knowledge flow patterns that have been created and sustained. Policy patterns 
determined that the initiation of regional innovation and knowledge stakeholders was prioritised, as was their interactions and their sustainability over time (RQ1).

In parallel, this distinctive path formation differentiated the ability of the two systems to generate, diffuse and exploit knowledge and skills (RQ2). In Sweden, as early as the 1980s, the development of the biotechnology sector was pro-actively supported through massive investments in knowledge infrastructures (supply-side orientation) (VINNOVA, 2007; VINNOVA, 2010). This investment, which was accompanied by the regionalisation of policies and the recognition of the third role of universities by the stakeholders, was concentrated in and around Lund University. LU's activities and incentives reinforced the original strengths of its research, following a largely "inside-out" direction (from endogenous knowledge generation to spin-off activities). As a result, LU became the engine of growth for biotechnology in the region. This long-term focus created a critical mass of knowledge generation and attracted international attention and recognition. The sustainability of the system in Skåne depends on the ability to foster, or indeed initiate, appropriate value chain networks, through its international knowledge networks. Such networks only partly explore the knowledge generation sphere, as they depend on the entrepreneurial nature of the participants. Therefore, in a second wave of investment a set of measures has been put in place oriented to triple-helix collaborations, financed mainly from VINNOVA, SSF and knowledge transfer institutions. These measures reinforced commercialisation processes and collaborations (e.g. IDEON science park, LU Innovation Systems), encouraging further startup creation. Furthermore, there was a strong economic agglomeration between universities and their spin- offs where local institutions mediate on connecting with financial institutions complementary to scientific networks. As a result, it is possible to identify an intense knowledge flow amongst universities and spin-offs, formulating a local "open self-sustained innovation paradigm", building networks that are characterised by a primarily socially 
embedded cohesion (HITE and HESTERLY, 2001). Despite this, the participation of start-ups of the region into international value chains remains a challenge.

The policy tools and programmes in Ireland have focused mainly on encouraging the establishment of productive operations either by foreign-owned firms across the country through FDI ("outside-in" orientation), or indigenous start-ups (FORFAS, 2000). These policies and programmes directed a first wave of foreign investments and spin-offs within the period from 1995 to 2000 and a second wave of MNEs interaction in the post-2000 period defining diverse needs, attractive to international value chains, forming local business and productive hubs. The Southern-Eastern biotechnology financial and investment initiatives are characterised by a risk-averse approach regarding value creation. Its sustainability depends on the ability of the dedicated-biotechnology firms (DBFs) to provide these specialised services and products, remain innovative, absorb knowledge and sustain productivity levels. The latter is connected with their knowledge absorption level and that of the region, which still depends on the role of national policies and supportive actions. In the past, these actions were fragmented and sporadic. These type of relations followed a path-dependent model, often within embedded and “arm's-length" relations.

\section{Conclusions}

The distinct characteristics of the two regions, codified in Appendix C, Figure C.1 and Figure C.2, give rise to a regional value generation concept for the two cases that demonstrates the level of achievement in the two regions under the theoretical lenses of the innovation systems theory. These illustrations follow the five subsystems of innovation systems theory, highlighting the regional characteristics that have been derived by the different formation paths. 
Innovation systems theory offers the generic intellectual framework to study innovation systems although it lacks sound suggestions regarding the process of formulating an overall system. The analysis of the two case studies presents an overall path of the flow of a value generation system's development, towards a complete and robust innovation system. These flows illustrate the importance of a coherent policy and investment approach incorporating the next generation of development. Synthesising the two distinctive frameworks (Figure 1) demonstrates two possible paths of projected development - the holistic "Regional ValueGeneration System”. Such projection may take into consideration the limitations of resources (capital, infrastructure, knowledge and human), the level of development or sophistication of its social capital and the evolutionary nature of regional and sectoral development.

In the case of Skåne-Blekinge, therefore, the next steps may include the enhancement of international networking activities in order to foster value-chain networks. Moreover, further initiatives are needed to enhance the internationalisation of start-ups, incorporating, for instance, open innovation business models and novel technology opportunities (e.g. technology platforms). In the case of Southern-Eastern, on the other hand, the next steps in its development could include further investment in basic and applied research oriented activities, selecting and investing in a few clear regional champions that can actually lead in the international research field. Moreover, the institutional and financial support mechanisms could be consolidated to support such champions.

\footnotetext{
$* * * * * * * * * * * * * * * * * * * * * *$
}

Figure 1 - Insert here

$* * * * * * * * * * * * * * * * * * * * * * *$

The proposition for the Southern-Eastern derives from the analysis of the two cases that expressed the need of concentrating resources on specific actors so as to avoid fragmentation. 
This aims to create poles of agglomeration or "champions". In both cases, when the resources (financial, infrastructure and human) were targeted, it created or attracted international champions. Those actors managed to evolve and develop adequate sophistication to reinforce their growth. This concentration is demonstrated especially by the relative success of LU compared to the Irish case where the knowledge generation and transfer system is fragmented. Politically, this is often hard to defend, as there are always local pressures. In one sense, this type of concentration is the reason for the successful formation of MNEs in comparison to the small spin-offs that often fail to grow sustainably. On the other hand, the actors that manage to grow in importance reinforce the original policies, influencing them only indirectly. The issue of the direction of the policies was raised in both regions, although it is questionable whether in the early stages these actors had the maturity to provide viable policies. As they progress in maturity, they are able to reinforce policies, which support their priorities. Thus, the presence of a knowledge champion, such as LU, has an influence on the regional priorities for Skåne-Blekinge and the dominant presence of MNEs dictates the industrial and economic policies of Ireland.

An investigation into the different patterns of development that emerge across the world could expand this work further. For example, based on the extended use of information technologies, which claim to break borders, it would be possible to observe the creation of "virtual (or “open”) innovation systems". These could be defined as interconnected stakeholders across different sectors, knowledge subjects, regions and nations where knowledge flows could be generated and transferred independent of the physical location. Furthermore, thematic clusters that engage academic, research and industry stakeholders from different fields (e.g. information technologies, physics, maths, engineering, hospitals and firms) and multi-level policy actors have been developed over the last decade across the world. The Catapults in the UK, Toronto's life sciences complex, the Pôles de Compétitivité in France, or the BioRegio 
programme in Germany (e.g. Heidelberg BioRegio cluster in Baden-Wurttemberg) represent such approaches at national level (FISKEN and RUTHERFORD, 2002; LOWE and GERTLER, 2009).

The further evolution of the Regional Value-Generation System may link directly with the governance structures of such mechanisms (bringing together research institutions, academia, private firms and even patients) and the contractual arrangements regarding the exploitation of their results. Open innovation arrangements in the biotechnology sector are here to stay and benefit from the specialisation of DBFs. Thus, innovative ways of organizing their development, financing their risky propositions, for example through crowdsourcing techniques, and commercializing biotechnologies will be crucial to growth in the business and the sector (ASHEIM, et al., 2011; PISANO, 2015).

In conclusion, this research reveals that for an innovation system to become self-sustaining requires consistency in path choice and a long-term coherent development. The original priorities or directions that are chosen define which relevant sub-systems should be prioritised for development by means of continuously evolving public policies and supportive actions. The realisation of this evolutionary strategy may lead even a small nation to succeed in a science-based sector, such as the biotechnology.

\section{NOTES}

${ }^{1}$ GDP per capita, 2010: $€ 37,300$ for Sweden; $€ 35,000$ for Ireland. GDP per capita, 2010, PPS: $€ 30,200$ for Sweden; $€ 31,600$ for Ireland (Eurostat).

${ }^{2}$ The dominant business models in biotechnology can be identified as: a) small or medium R\&D oriented firms (Dedicated Biotechnology Firms or DBFs), which originate as university 
spin-offs or spin-outs from major firms and develop specialised research, license intellectual property or provide R\&D services; b) large multinational companies, conducting world-class research and commercialization functions under vertical or 'virtual' integrations (FISKEN and RUTHERFORD, 2002).

${ }^{3}$ Major knowledge actors in the region, Appendix A, Table A.2.

${ }^{4}$ More than 30 companies have received support in the form of facilities through the IDEON science park, 14 from other incubators and 25 from other independent business parks around the region. In the case of Southern-Eastern, 19 firms are based in incubators, MNEs are mostly located in independent sites or IDA business parks.

${ }^{5}$ Main national actors in Ireland and diffusion institutions in Southern-Eastern, Appendix A, Table A.2 and Table A.6.

${ }^{6}$ Elan Corporation was launched in 1969 specialising in drug delivery systems. After 2002, a divesting strategy caused spin out effects (i.e. such as AGI Therapeutics) (CURRAN et al, 2011).

\section{REFERENCES}

ADAMS, J.D. (2002) Comparative localization of academic and industrial spillovers, Journal of Economic Geography 2, 253-278.

ADLER, P. S. and KWON, S-W. 2002 'Social capital: prospects for a new concept', Academy of Management Review, 27 (1), 17-40.

ANGELAKIS, A. (2011) Regional Competitiveness and Research, Technology and Innovation Policies, PhD Thesis, University of Crete, Greece. 
ASHEIM, B. and COENEN, L. (2005) Knowledge bases and regional innovation systems: Comparing Nordic clusters. Research Policy 34, 1173-1190.

ASHEIM, B., BOSCHMA, R. and COOKE, P. (2011) Constructing Regional Advantage: Platform Policies Based on Related Variety and Differentiated Knowledge Bases. Regional Studies 45, 893-904.

AUTANT-BERNARD, C., FADAIRO, M. and MASSARD, N. (2013) Knowledge diffusion and innovation policies within the European regions: Challenges based on recent empirical evidence. Research Policy, 42, 196-210.

AUTANT-BERNARD, C. and LESAGE, J. (2011) Quantifying knowledge spillovers using spatial econometric tools. Journal of Regional Science 51, 471-496.

BANERJEE, P.M. and COLE, B.M. (2012) A study of biotechnology start-ups undergoing leadership change: Antecedents of change and endogenous performance consequences. Technovation 32, 568-578.

BITARD, P., EDQUIST, C., HOMMEN, L and RICKNE, A. (2008) Reconsidering the paradox of high R\&D input and low innovation: Sweden. In: EDQUIST, C. and HOMMEN, L. (Eds.) Small Country Innovation Systems Globalization, Change and Policy in Asia and Europe, Edward Elgar.

BOTTAZZI, L. and PERI, G. (2003) Innovation and spillovers in regions: evidence from European patent data. European Economic Review 47, 687-710.

BURT, R. (1992) Structural holes versus network closure as social capitl. In: LIN, N., COOK, K., and BURT, R. (Ed.) (2001) Social Capital: Theory and Research. NY: Aldine DE Gruyter. 
CARLSSON, B., JACOBSSON, S., HOLMÉN, M. and RICKNE, A. (2002) Innovation systems: analytical and methodological issues. Research Policy 31, 233-245.

CASPER, S. (2007) How do technology clusters emerge and become sustainable?: Social network formation and inter-firm mobility within the San Diego biotechnology cluster. Research Policy 36, 438-455.

CHESBROUGH, H. (2003) Open Innovation: The New Imperative for Creating and Profiting from Technology. Harvard Business School Press, Boston.

COENEN, L. (2007) The role of universities in the regional innovation systems of the North East of England and Scania, Sweden: providing missing links?. Environment and Planning C: Government and Policy 25, 803-821.

COLLIS, J. and HUSSEY, R. (2003) Business Research: A Practical Guide for Undergraduate and Postgraduate Students. Palgrave Macmillan., UK.

CRESCENZIA, R, GAGLIARDIA, L. and IAMMARINO, S. (2015) Foreign multinationals and domestic innovation: Intra-industry effects and firm heterogeneity, Research Policy 44, 596-609.

CURRAN, D., VAN EGERAAT, C. and O'GORMAN, C., (2011) New Entrants and Inherited Competence: The Evolution of the Irish Biotech Sector. NIRSA Working Paper Series 66.

EDQUIST, C., (Editor) (1997) Systems of Innovation: Technologies, Institutions and Organizations, Pinter.

EDQUIST, C. (2011) Design of innovation policy through diagnostic analysis: Identification of systemic problems (or failures). Industrial and Corporate Change 20, 1-29. 
ENTERPRISE IRELAND (2011) Technology Transfer in Ireland 2007-2010. Enterprise Ireland, Dublin.

FISKEN, J. and RUTHERFORD, J. (2002) Business models and investment trends in the biotechnology industry in Europe. Journal of Commercial Biotechnology 8, 191-199.

FORAY, D. and MAIRESSE, J. (2002) The knowledge dilemma and the geography of innovation. In: FELDMAN, M. and MASSARD, N. (Eds.), Institutions and Systems in the Geography of Innovation. Kluwer Academic Publishers, Boston/Dordrecht/London, pp. 3554.

FORFAS (2000) Enterprise 2010: A New Strategy for the Promotion of Enterprise in Ireland in the 21st Century, Dublin: Forfás.

FORFAS (2011) Analysis of Ireland's Innovation Performance, Dublin.

GALANAKIS, K. (2006) Innovation process. Make sense using systems thinking.

Technovation 26, 1222-1232.

GERTLER M. S. and LEVITTE Y. M. (2005) Local nodes in global networks: the geography of knowledge flows in biotechnology innovation, Industry and Innovation 12, 487-507.

GÖRANSSON, B. and PÅLSSON, C.M. (2011) Strategies for appropriation of biotechnology. In: GÖRANSSON, B. and PÅLSSON, C.M. (Eds.) Biotechnology and Innovation Systems: The Role of Public Policy. Edward Elgar, Cheltenham, UK - Northampton, MA, USA., pp. 110.

GUAN, J., ZHANG, J. and YAN, Y. (2015) The impact of multilevel network on innovation. Research Policy, 44, 545-559. 
HALL, B. (2002) The Financing of Research and Development. Oxford Review of Economic Policy $18,35-51$.

HENNING, M., MOODYSSON, J. and NILSSON, M. (2010) Innovation and Regional Transformation: From Clusters to New Combinations. Region Skane, Malmo, Sweden.

HEWITT-DUNDAS, N. and ROPER, S. (2008) Ireland's Innovation Performance: 1991-2005. Quarterly Economic Commentary, Vol. 2008 (2), 06.2008, 46-68.

HILLIARD, R. and GREEN, R., (2005) Governance and Institutional Change in Ireland. In: Organisation for Economic Co-operation and Development, OECD (Ed.), Governance of Innovation Systems, Volume 2. Case Studies in Innovation Policy. OECD, Paris, pp. 43-64.

HITE, J. and HESTERLY, W. (2001) The evolution of firm networks: from emergence to early growth of the firm, Strategic Management Journal 22, 275-286.

HOPKINS, M.M., MARTIN, P.A., NIGHTINGALE, P., KRAFT, A. and MAHDI, S. (2007) The myth of the biotech revolution: An assessment of technological, clinical and organisational change. Research Policy 36, 566-589.

IDA (2011) Agenda 2000 Regionalisation Arrangements Industrial Development Agency, Ireland, http://www.idaireland.com/, access at: 09/03/2011.

INTERTRADEIRELAND (2003) Mapping the Bio-Island. A North/South Study of the Private Biotechnology Sector. InterTradeIreland, Co. Down, Ireland.

INVEST IN SKANE, http://www.investinskane.com, access at: 12/05/2010. 
KUHLMANN, S. (2001) Future governance of innovation policy in Europe - three scenarios, Research Policy 30, pp. 953-976.

LOWE N. and GERTLER M. (2009) Building on diversity: institutional foundations of hybrid strategies in Toronto's life sciences complex, Regional Studies 43, 589-603.

LUNDVALL, B. Å., (Editor) (1992) National Systems of Innovation. Toward a Theory of Innovation and Interactive Learning, Pinter, London.

LUNDVALL, B. Å. and BORRAS, S. (2005) Science, Technology and Innovation Policy. In: FAGERBERG, J., MOWERY, D., NELSON, R. (Eds.), The Oxford Handbook of Innovation. Oxford University Press, Oxford, pp. 599-631.

MIGUÉLEZ, E. and MORENO, R. (2015) Knowledge flows and the absorptive capacity of regions. Research Policy, 44, 833-848.

MUKHERJI, N. and SILBERMAN, J. (2013) Absorptive capacity, knowledge flows, and innovation in US metropolitan areas. Journal of Regional Science 53, 392-417.

NAUWELAERS, C. and WINTJES, R., (Ed.) (2008) Innovation Policy in Europe. Edward Elgar, Cheltenham.

NELSON, R. R., (Editor) (1993) National Innovation Systems. A Comparative Analysis, Oxford University Press.

OECD (2002) Redefining Territories: The Functional Regions, Paris: OECD.

OECD (2006) The Øresund Science Region: A cross-border partnership between Denmark and Sweden, Peer Review Report, OECD. 
PHARMACHEMICAL IRELAND (2011) Ireland: The Location of Choice for Scientific Investment. IBEC, Dublin.

PISANO, G. (2006) Science Business: The Promise, the Reality, and the Future of Biotech. Harvard Business School Press, Boston, Massachusetts.

PISANO, G. (2015) You need an innovation strategy (June Issue), Harvard Business Review.

RAHM, D., KIRKLAND, J. and BOZEMAN, B. (2000) University-Industry R\&D

Collaboration in the United States, the United Kingdom, and Japan. Springer, London.

REICHERTZ, J. (2007) Abduction: The logic of discovery of grounded theory. In: BRYANT, A. and CHARMAZ, K. (Eds.) The Sage Handbook of Grounded Theory, pp. 215-228, Los Angeles, CA: Sage.

SENKER, J., ENZING, C., JOLY, P. and REISS, T. (2000) European exploitation of biotechnology - do government policies help. Nature Biotechnology 18, 605-609.

SINGH, J. and AGRAWAL, A. (2011) Recruiting for ideas: how firms exploit the prior inventions of new hires. Manage. Sci. 57, 129-150.

SPRU (2007) BioPolis - Inventory and analysis of national public policies that stimulate research in biotechnology, its exploitation and commercialisation by industry in Europe in the period 2002-2005. National Report of IRELAND.

TER WAL, A.L.J. and BOSCHMA, R. (2011) Co-evolution of Firms, Industries and Networks in Space. Regional Studies 45, 919-933. 
TÖDTLING, F. and TRIPPL, M., 2005. One size fits all?: Towards a differentiated regional innovation policy approach. Research Policy 34, 1203-1219.

VALE, M. and CARVALHO, L. (2013) Knowledge Networks and Processes of Anchoring in Portuguese Biotechnology, Regional Studies, Vol. 47, No. 7, 1018-1033.

VINNOVA (2007) Effects of VINNVÄXT in Swedish Regions, Final Report.

VINNOVA (2010) VINNVÄXT at the halfway mark: experiences and lessons learned.

YIN, R. (1994) Case Study Research: Design and Methods (Applied Social Research Methods), 2nd ed. Sage Publication, USA.

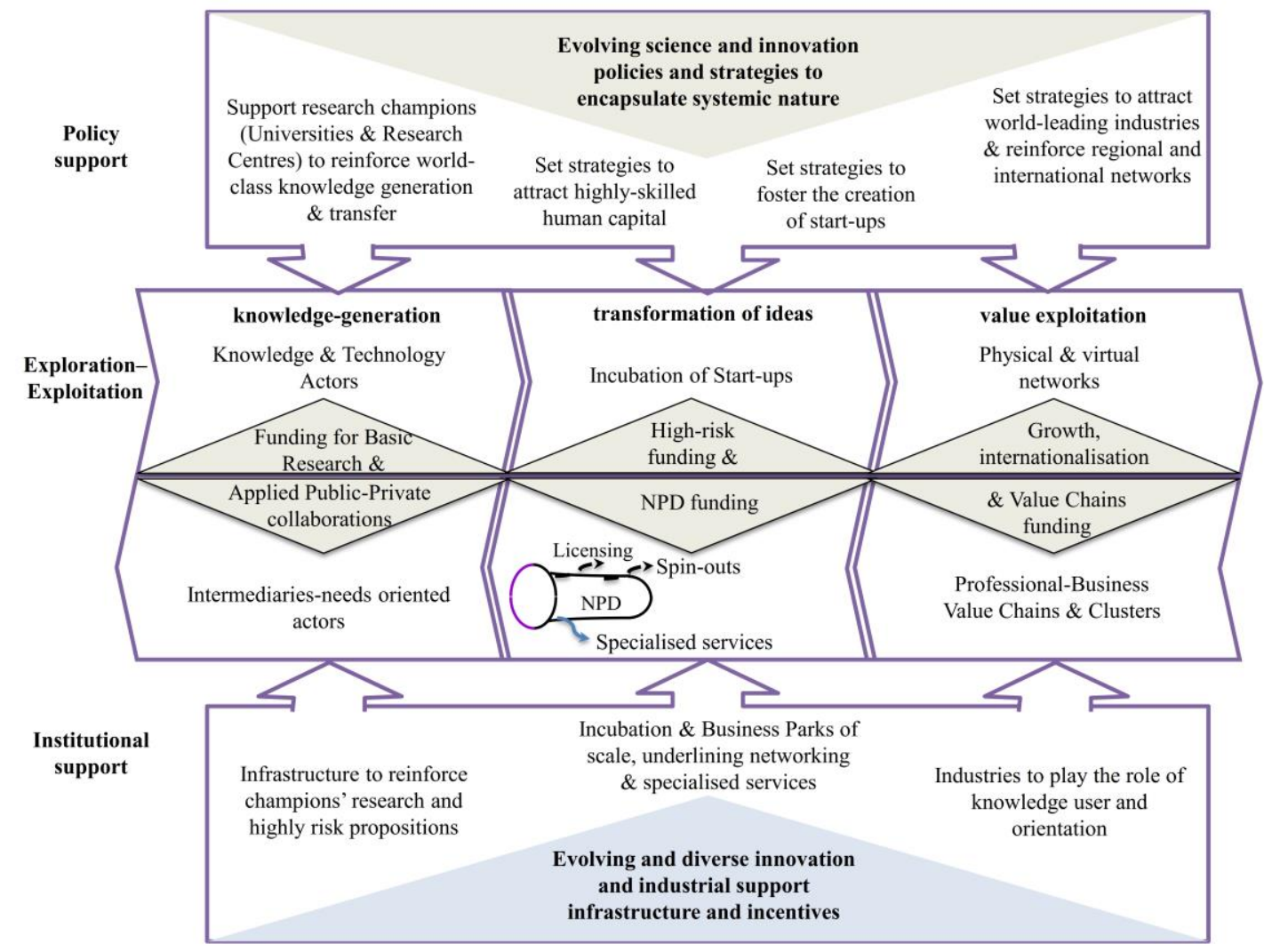

Fig. 1. Regional value-generation system 
Table 1. Comparison of regional systems - the institutional dimension

\begin{tabular}{|c|c|c|}
\hline & Skåne & Southern-Eastern \\
\hline $\begin{array}{l}\text { National policies } \\
\text { before mid-90's }\end{array}$ & $\begin{array}{l}\text { Proactive science and technology } \\
\text { policy for specific sectors } \\
\text { - Systemic recognition on the } \\
\text { importance of knowledge } \\
\text { economy } \\
\text { - Gradual recognition on the third } \\
\text { role (developmental) of } \\
\text { universities and research } \\
\text { institutions }\end{array}$ & $\begin{array}{l}\text { - Orientation towards Foreign } \\
\text { Direct Investments } \\
\text { Gradual recognition of the need } \\
\text { to support indigenous industry } \\
\text { and specific sectors } \\
\text { Formulation of strong } \\
\text { enterprise base around } \\
\text { academic centres business } \\
\text { parks and across the region }\end{array}$ \\
\hline $\begin{array}{l}\text { National policies } \\
\text { since mid-90's }\end{array}$ & 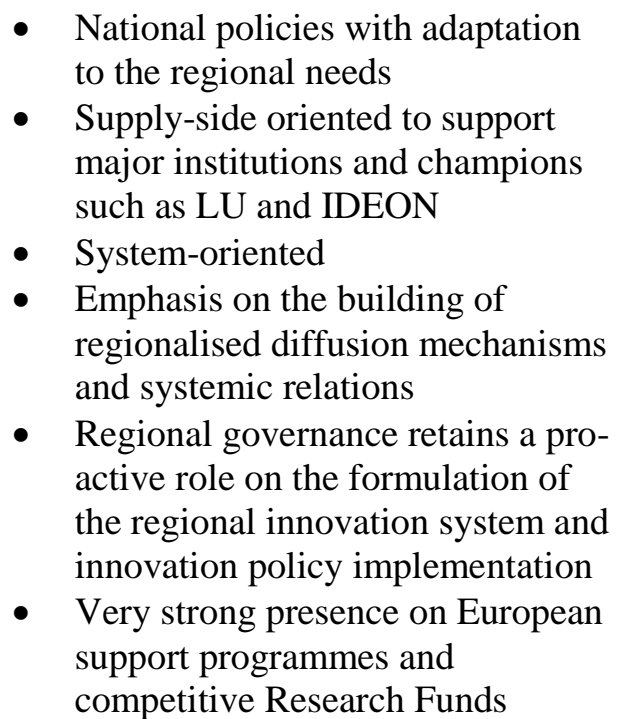 & $\begin{array}{l}\text { - Centrally designed in national } \\
\text { level } \\
\text { - Policy focused on few strategic } \\
\text { sectors } \\
\text { - Multi-level but fragmented with } \\
\text { supporting mechanisms for } \\
\text { indigenous and foreign-owned } \\
\text { companies } \\
\text { - Recognition of the need for } \\
\text { systemic orientation } \\
\text { - Regional governance retains a } \\
\text { limited role on innovation } \\
\text { policy design and } \\
\text { implementation } \\
\text { - Very active presence on } \\
\text { European Structural Funds }\end{array}$ \\
\hline
\end{tabular}

Source: ENTERPRISE IRELAND, 2011; FORFAS, 2011; VINNOVA, 2007, 2009a, 2009b, 2010;

OECD, 2003.

Table 2. Sector's major features

\begin{tabular}{|c|c|c|c|c|c|c|c|c|c|c|}
\hline \multicolumn{5}{|c|}{ No of firms in operation by period } & \multicolumn{6}{|c|}{ No of firms in operation after 2006, by } \\
\hline \multirow[b]{2}{*}{ Period } & \multicolumn{2}{|c|}{ Total } & \multicolumn{2}{|c|}{$\begin{array}{c}\text { Universities' } \\
\text { spin-offs }\end{array}$} & \multicolumn{3}{|c|}{ Origin } & \multicolumn{3}{|c|}{ Size } \\
\hline & Skåne & S-E & Skåne & S-E & & Skåne & S-E & & Skåne & S-E \\
\hline $\begin{array}{l}\text { Before } \\
1990\end{array}$ & 8 & 16 & 4 & 0 & \multirow{2}{*}{$\begin{array}{l}\text { Universities } \\
\& \text { institutes } \\
\text { spin-offs }\end{array}$} & 37 & 28 & Micro & 52 & 24 \\
\hline $\begin{array}{l}1991- \\
1995\end{array}$ & 16 & 19 & 5 & 0 & & & & Small & 8 & 25 \\
\hline $\begin{array}{l}1996- \\
2000\end{array}$ & 23 & 40 & 4 & 13 & $\begin{array}{l}\text { Large firms } \\
\text { spin-outs }\end{array}$ & 3 & 7 & Medium & 8 & 12 \\
\hline $\begin{array}{l}2001- \\
2005\end{array}$ & 37 & 61 & 6 & 11 & $\begin{array}{l}\text { MNE's } \\
\text { subsidiaries }\end{array}$ & 2 & 17 & Large & - & 6 \\
\hline $\begin{array}{l}\text { After } \\
2006\end{array}$ & 68 & 67 & 18 & 4 & $\begin{array}{l}\text { Indigenous } \\
\text { start-ups }\end{array}$ & 26 & 15 & & & \\
\hline
\end{tabular}


Source: FORFAS, 2009a, 2009b, 2011; VINNOVA, 2007, 2009a, 2009b, 2010; OECD, 2006; Organizations' websites: European Patent Office/espacenet, IDA, Invest in Skane, Irish Software Association, Medicon Valley, Science Foundation Ireland, VINNOVA.

Table 3. Segments, business models and source of co-funding

\begin{tabular}{|c|c|c|c|c|c|c|c|c|}
\hline \multicolumn{9}{|c|}{ No of firms in operation after 2006, by } \\
\hline \multicolumn{3}{|c|}{ Segment } & \multicolumn{3}{|c|}{ Business model } & \multicolumn{3}{|c|}{ Source of co-funding } \\
\hline & Skåne & S-E & & Skåne & S-E & & Skåne & S-E \\
\hline Bio-pharma & 36 & 25 & $\begin{array}{l}\text { Product } \\
\text { oriented }\end{array}$ & 40 & 42 & $\begin{array}{l}\text { Venture } \\
\text { Capital and/or } \\
\text { supported by } \\
\text { major bio- } \\
\text { pharma firms }\end{array}$ & 56 & 41 \\
\hline Diagnostics & 7 & 8 & $\begin{array}{l}\text { Platforms } \\
\text { (Specialised } \\
\text { Services) }\end{array}$ & 20 & 24 & $\begin{array}{l}\text { Publicly listed } \\
\text { companies }\end{array}$ & 12 & 26 \\
\hline Therapeutics & 8 & 7 & $\begin{array}{l}\text { Therapies/ } \\
\text { treatments }\end{array}$ & 8 & 1 & & & \\
\hline $\begin{array}{l}\text { Bio-analytic } \\
\text { services }\end{array}$ & 3 & 7 & & & & & & \\
\hline Bio-materials & 5 & 8 & & & & & & \\
\hline Bio-food & 4 & 6 & & & & & & \\
\hline Other & 5 & 6 & & & & & & \\
\hline
\end{tabular}

Source: FORFAS, 2009a, 2009b, 2011; VINNOVA, 2007, 2009a, 2009b, 2010; OECD, 2006; Organizations' websites: European Patent Office/espacenet, IDA, Invest in Skane, Irish Software Association, Medicon Valley, Science Foundation Ireland, VINNOVA.

Table 4. Regional systems' business environment comparison

\begin{tabular}{|c|c|c|}
\hline & $\begin{array}{ll}\text { Skåne } \\
\end{array}$ & Southern Eastern \\
\hline Growth period & $\begin{array}{l}\text { - First companies established in } \\
\text { the mid-80s till mid-90s } \\
\text { - Acceleration starts at the } 2000 \mathrm{~s}\end{array}$ & $\begin{array}{l}\text { - Most established by late 1990s, } \\
\text { attracted by IDA initiatives. } \\
\text { - Half of firms are MNEs or } \\
\text { MNEs' spin-outs. }\end{array}$ \\
\hline $\begin{array}{l}\text { Structure of the } \\
\text { sector }\end{array}$ & $\begin{array}{l}\text { LU spin-offs are the drivers of } \\
\text { activity } \\
\text { - Employment is fragmented into } \\
\text { a large number of micro \& } \\
\text { small firms }\end{array}$ & $\begin{array}{l}\text { - More than } 20 \text { MNE's present in } \\
\text { the region } \\
\text { - MNE's are the drivers of } \\
\text { activity and employment }\end{array}$ \\
\hline Major segments & $\begin{array}{l}\text { - } \text { Bio-pharma } \\
\text { - Therapeutics } \\
\text { - } \text { Diagnostics }\end{array}$ & $\begin{array}{l}\text { - } \text { Bio-pharma } \\
\text { - } \text { Diagnostics } \\
\text { - } \text { Bio-materials } \\
\text { - } \text { Bio-analytic services } \\
\text { - Bio-food }\end{array}$ \\
\hline
\end{tabular}




\begin{tabular}{|c|c|c|}
\hline Business models & 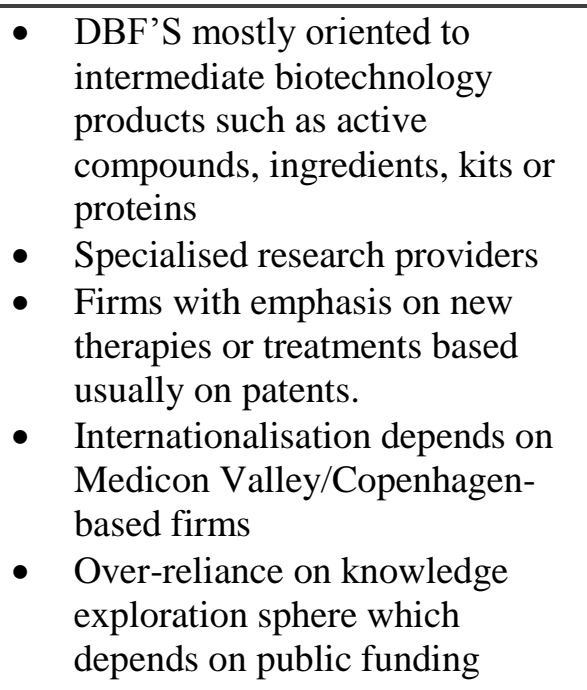 & $\begin{array}{l}\text { - } \begin{array}{l}\text { MNE's oriented to drug } \\
\text { delivery }\end{array} \\
\text { DBF's dependence on MNE's } \\
\text { investments, activities and } \\
\text { specialisations - benefited by } \\
\text { MNEs' international supply } \\
\text { chains. } \\
\text { - Over-reliance on public-backed } \\
\text { VC mechanisms }\end{array}$ \\
\hline $\begin{array}{l}\text { Major ownership } \\
\text { schemes }\end{array}$ & $\begin{array}{l}\text { Multi-partite schemes: Holding } \\
\text { companies with VC } \\
\text { participation }\end{array}$ & $\begin{array}{l}\text { - Publicly Listed Companies } \\
\text { - Publicly backed VC companies }\end{array}$ \\
\hline Source of finance & $\begin{array}{l}\text { - National and international } \\
\text { private VCs } \\
\text { - } \text { Regional public \& EU } \\
\text { supported funding networks and } \\
\text { organisations }\end{array}$ & $\begin{array}{l}\text { - Publicly supported VC } \\
\text { mechanisms and schemes in } \\
\text { national level } \\
\text { - Lack of regional mechanisms } \\
\text { - Lack of seed capital }\end{array}$ \\
\hline $\begin{array}{l}\text { Strategic } \\
\text { actors/couplings }\end{array}$ & $\begin{array}{ll}\text { - } & \text { Lund University } \\
\text { - } & \text { Medicon Valley }\end{array}$ & - Pharmaceutical MNE's \\
\hline
\end{tabular}

Table 5. Summary of interviewees' perceptions regarding the innovation policy and structures

Key perceptions, Skåne Key perceptions, Southern-Eastern


- Radical shift towards innovation system approach since mid 1990s. Emphasis on:

○ public-private collaboration,

$\circ$ the 'third' role of universities (triple helix model)

- Shift of responsibility for economic development:

○ 'Functional Regions'

○ Regional Agreements

- National policy actors, such as VINNOVA, direct regional policy \& investment priorities

- Compliance with the national policy objectives.

- Explicit recognition for the strategic economic importance of life sciences and biotechnology by all the stakeholders - central factor to the regional agreements.

- Many active regional networks and 'triple helix' type collaborations, especially in the Medicon Valley area:

- Systemic role of LU in public-private partnerships and developing initiatives for knowledge exploration and exploitation,.

- Major role of specialised regional knowledge transfer mechanisms, especially around LU.

- Regional and national funding actors have evolved significantly, e.g. Universities' holding companies and public-funded venture capitals.

- Sector-oriented private funding mechanisms active in the region with national or international activity (e.g. Stockholm, Copenhagen)

- Seed capital needs further maturity.
- Gradual evolution to knowledge based economy and innovation systems mentality since late 1990s.

○ National policy actors are major funding mechanisms and drivers of change at the level of design and implementation;

- National programmes, e.g. Technology Transfer Initiative, incubation and business supporting mechanisms ignited knowledge transformation activity - limited initial interest and scale of activities.

- Need of a higher degree of coordination to create economies of scale and scope.

- Regional development based on the EU cofinanced Operational Programme, with focus on developing infrastructure:

- Regional agencies and assembles have partial role on design;

○ Fragmented and of limited scale.

- Recognition of the biotechnology sector as a priority for industrial investment:

- National mechanisms, e.g. Enterprise Ireland, backing public-private collaboration initiatives.

○ Universities and Technology Institutes still to fulfil their potential in knowledge exploration and knowledge exploitation.

- Major role of MNEs:

- Developed productive activity

- Limited R\&D capabilities or active and sustainable collaborations.

- Seed and VC Schemes are mainly publicbacked initiatives

\section{APPENDIX}

\section{Appendix A. The Institutional Formation in the two regions}

Table A.1. Organisations interviewed for this research 


\begin{tabular}{|l|l|}
\hline Skåne, Sweden & Southern-Eastern, Ireland \\
\hline Öresund Food Platform & IDA \\
LU Food Science AB & Forfas \\
Lund Bioinkubator & Science Foundation Ireland \\
IDEON Science Park/IDEON Innovation & Research and Training (NIBRT) \\
Öresund IT & University College Dublin technology transfer \\
Öresund Entrepreneurship Platform & office \\
Region Skåne/Invest in Skåne & Trinity Research \& Innovation - Trinity College \\
Connect Skåne & Enterprise Ireland \\
\hline LU Innovation & \\
\hline
\end{tabular}

Note: the interviews were conducted in August 2010 (Skåne) and September 2010 (SouthernEastern)

Table A.2. Main National Actors

\begin{tabular}{|l|l|}
\hline Sweden & Ireland \\
\hline
\end{tabular}




\begin{tabular}{|l|l|}
\hline The Ministry of Enterprise, Energy and & The Department of Jobs, Enterprise and \\
Communications, oversees VINNOVA; & Innovation; \\
The Ministry for Research and Education; & Forfás; \\
The Swedish Research Council FORMAS; & Industrial Development Agency (IDA); \\
Independent research foundations (e.g. Swedish & Enterprise Ireland (EI); \\
Foundation for Strategic Research - SFF); & Higher Education Authority (HEA) and \\
The Swedish Agency for Economic and & Science Foundation Ireland (SFI) \\
Regional Growth (Tillväxtverket - former & \\
NUTEK) & \\
\hline
\end{tabular}

Table A.3. Programmes implemented in Skåne, on biotechnology

\begin{tabular}{|l|l|l|l|}
\hline Programme & Major beneficiary & Contributors & Outcome \\
\hline Swedish Competence & LU; Fifteen industrial & NUTEK & BioSep Centre \\
Centres programme & $\begin{array}{l}\text { partners (e.g. Active } \\
\text { Biotech) }\end{array}$ & one third private financial & \\
& contribution & & \\
\hline
\end{tabular}




\begin{tabular}{|c|c|c|c|}
\hline $\begin{array}{l}\text { Molecular and Cellular } \\
\text { Plant Biology }\end{array}$ & LU & $\begin{array}{l}\text { Swedish Foundation for } \\
\text { Strategic Research (SSF) }\end{array}$ & Basic research results \\
\hline $\begin{array}{l}\text { Postgenomic Research } \\
\text { and Technology } \\
\text { Programme }\end{array}$ & $\begin{array}{l}\text { LU, Gothenburg } \\
\text { University and Chalmers } \\
\text { University of } \\
\text { Technology in } \\
\text { Gothenburg }\end{array}$ & $\begin{array}{l}\text { Wallenberg Foundation } \\
\text { support by the SSF }\end{array}$ & $\begin{array}{l}\text { Swegene Centre for Integ } \\
\text { (SCIBLU), LU }\end{array}$ \\
\hline $\begin{array}{l}\text { Biomedical Centre } \\
(\mathrm{BMC})\end{array}$ & $\begin{array}{l}\text { LU: over } 100 \text { research } \\
\text { teams }\end{array}$ & $\mathrm{LU}$ & Basic and Applied researcl \\
\hline Biomolecular Dynamics & $\mathrm{LU}$ & SSF & Basic research results \\
\hline $\begin{array}{l}\text { Lund Centre for Stem } \\
\text { Cell Biology and Cell } \\
\text { Therapy }\end{array}$ & $\mathrm{LU} / \mathrm{BMC}$ & SSF & $\begin{array}{l}\text { One of the six Swedish str } \\
\text { of excellence in life scienc }\end{array}$ \\
\hline $\begin{array}{l}\text { Food Innovation at } \\
\text { Interfaces (FII) }\end{array}$ & $\begin{array}{l}\text { LU } \\
\text { More than } 140 \\
\text { companies; } 70 \\
\text { researchers; } 80 \text { projects } \\
\text { (FISKEN and } \\
\text { RUTHERFORD, 2002) }\end{array}$ & VINNOVA & $\begin{array}{l}\text { LU launched the Lund Foc } \\
\text { Centre }\end{array}$ \\
\hline Linneaus grants & $\begin{array}{l}\text { Consortium of research } \\
\text { groups, LU }\end{array}$ & $\begin{array}{l}\text { Swedish Research } \\
\text { Council }\end{array}$ & LU Diabetes Centre (LUD \\
\hline
\end{tabular}




\begin{tabular}{|l|l|l|l|}
\hline Clinical Research & Malmo & Lund University; Region & Basic research results \\
Centre & Skåne & \\
Strategic Centre for & LU /BMC & SFF, Knut and Alice & 3 world-wide patents per y \\
Translational Cancer & Wallenberg Foundation & first five years; 6 spin-off \\
research & and VINNOVA & already grown to more tha \\
VINN Excellence & LU industry & VINNOVA (22 million & Antidiabetic Food Centre \\
Centres & collaboration (e.g. & euros for 10 years) & the fifteen excellence cent \\
& Aventure AB) & & \\
\end{tabular}

Table A.4. Knowledge Transformation Organisations in Skåne, Life Sciences/Biotechnology

\begin{tabular}{|l|cc|}
\hline \multicolumn{2}{|c|}{ Category/Name } & Location \\
\hline \multicolumn{2}{|c|}{ Science Parks } \\
\hline IDEON & & Lund \\
\hline Medeon & & Malmo \\
\hline Krinova Science Park & & \\
\hline & Incubators \\
\hline Ideon Innovation & Lund \\
\hline
\end{tabular}




\begin{tabular}{|l|c|}
\hline Lund Bioinkubator & Lund \\
\hline Venture Lab & Lund \\
\hline Lund Life Science Incubator (LLSI) & Lund \\
\hline P.U.L.S. & Helsinborg \\
\hline Alnarp Innovation Inkubator & Alnarp \\
\hline \multicolumn{2}{|c|}{ Technology Transfer } \\
\hline Lund University Innovation Systems AB (LUIS AB \\
\hline Forskarpatent i Syd AB & Lund \\
\hline Innovation Office South-Innovationskontor Syd & Blekinge, Kristianstad, Lund, Malmo, Alna \\
\hline Ideon Agro Food & Lund \\
\hline \multicolumn{2}{|c|}{ Business support } \\
\hline Teknoseed AB & Lunding mechanisms \\
\hline Teknopol AB & Lund \\
\hline Lund Development AB & Lund \\
\hline LU Food Science AB & Lund \\
\hline LU BioScience AB & Lund \\
\hline Högskolan Kristianstad Holding AB & Lund \\
\hline Innovator Skåne AB & Lund \\
\hline Technopol AB & Lund \\
\hline
\end{tabular}




\begin{tabular}{|l|c|}
\hline Technoseed AB & Lund \\
\hline Innovation Bridge & Lund \\
\hline LU University Bioscience AB (LU Bio) & Lund \\
\hline LUBioAccelerator & Lund \\
\hline
\end{tabular}

Table A.5. Major programmes supported biotechnology in Southern-Eastern, 1998-2010

\begin{tabular}{|l|c|c|c|}
\hline Programme & Major beneficiary & Contributor & Outcomes \\
& & & \\
\hline Principal Investigators & $\begin{array}{r}\text { Academic/research } \\
\text { centers }\end{array}$ & SFI & Academic/research centers \\
\hline
\end{tabular}




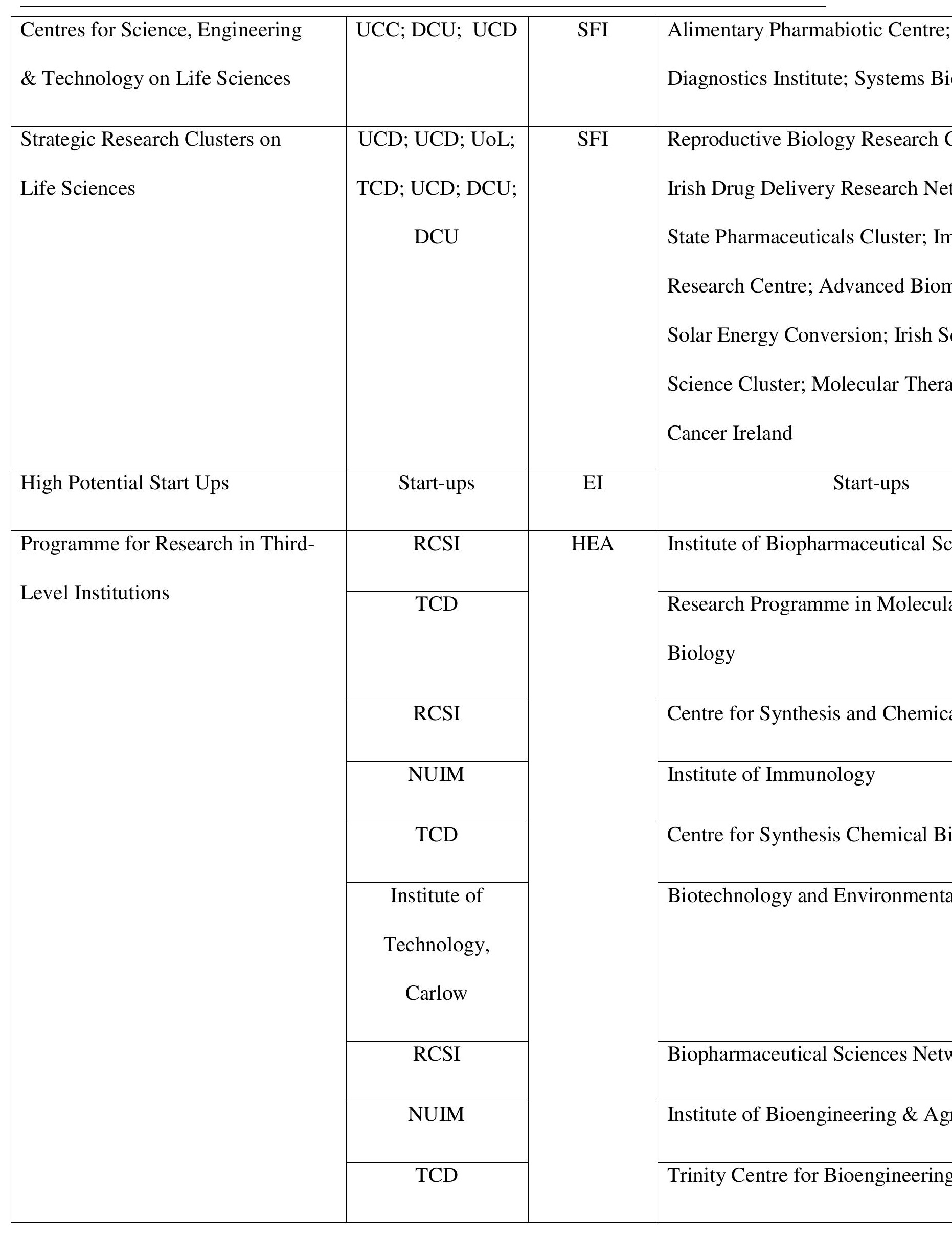




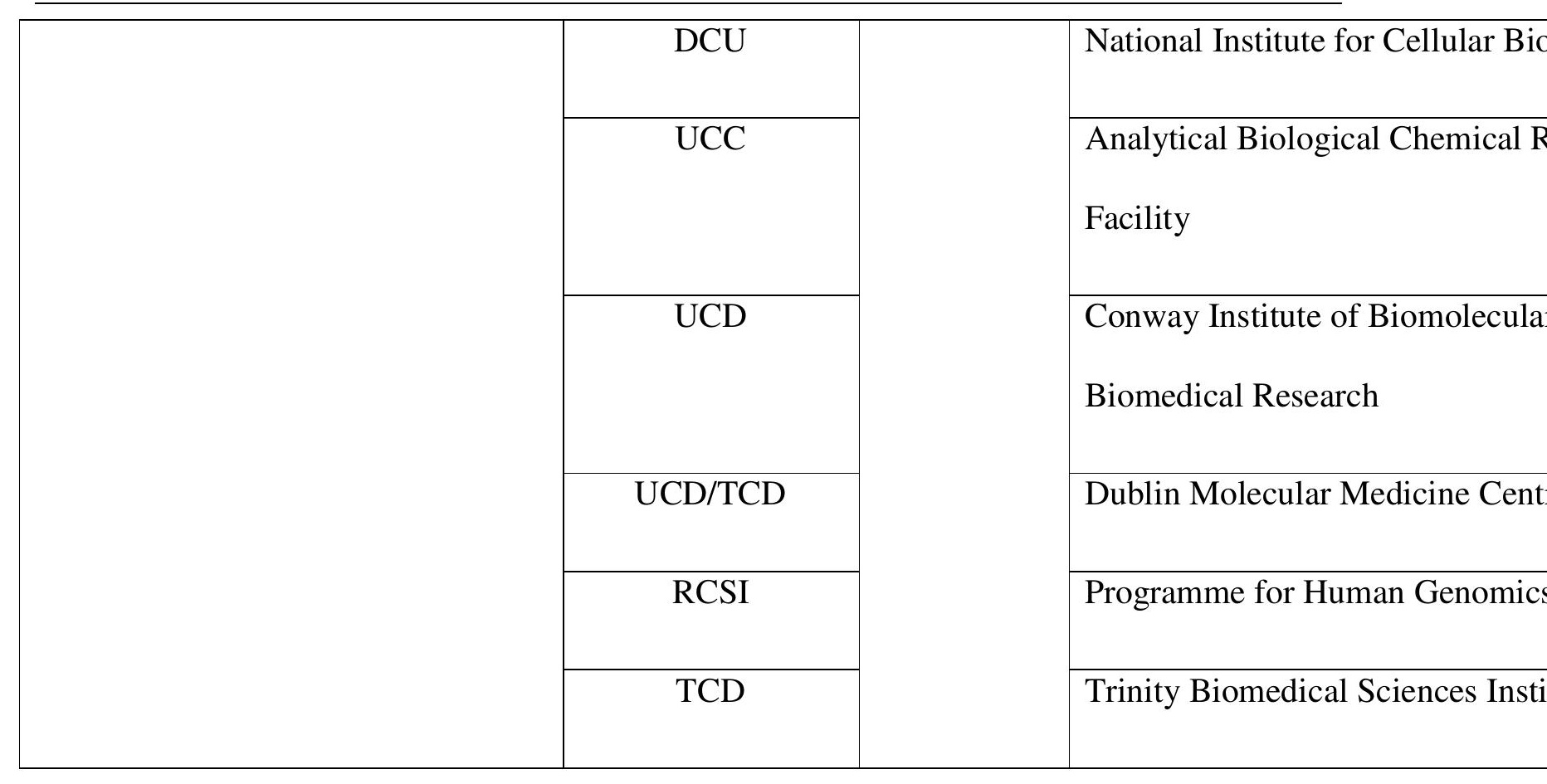


Table A.6. Major Knowledge Diffusion Institutions in Southern-Eastern

\begin{tabular}{|c|c|}
\hline Category/Name & Location \\
\hline \multicolumn{2}{|c|}{ Incubators with biotechnology activity in Institutes of Technology } \\
\hline Learning \& Innovation Centre (LINC) & $\begin{array}{c}\text { Blanchardstown Institute of } \\
\text { Technology }\end{array}$ \\
\hline DIT Incubation Centre & Dublin Institute of Technology \\
\hline Enterprise Acceleration Centre & Limerick Institute of Technology \\
\hline Tom Creen Business Centre & Institute of Technology Tralee \\
\hline Arclabs Research and Innovation Centre & Waterford Institute of Technology. \\
\hline \multicolumn{2}{|c|}{ Bio-Incubators in Universities/Hospitals } \\
\hline University College Cork & Cork \\
\hline Dublin City University & Dublin \\
\hline Trinity Technology \& Enterprise Campus, TCD & Dublin \\
\hline Nova UCD & Dublin \\
\hline St. James Hospital & Dublin \\
\hline \multicolumn{2}{|c|}{ Technology Transfer Mechanisms } \\
\hline Technology Transfer Initiative & National level/EI \\
\hline University College Dublin (UCD) & Dublin \\
\hline Dublin City University (DCU) & Dublin \\
\hline University College Cork (UCC) - BioTransfer Unit & Cork \\
\hline NUI Maynooth & Maynnoth \\
\hline
\end{tabular}




\begin{tabular}{|l|c|}
\hline Trinity College Dublin & Dublin \\
\hline Royal College of Surgeons Ireland (RCSI) & Dublin \\
\hline Dublin Institute of Technology (DIT) & Limerick \\
\hline University of Limerick (UL) & Waterford \\
\hline Waterford Institute of Technology (WIT) Funding from EI & Investments/millions \\
\hline \multicolumn{1}{|c|}{ Programme } & More than $€ 350$ \\
\hline Seed and Venture Capital Scheme, 1994- & $€ 12.7$ \\
\hline Irish BioScience Venture Capital Fund, 2001 & $€ 75$ \\
\hline European BioScience Fund I, 2002- & $€ 17$ \\
\hline Atlantic Bridge II Limited partnership Fund, 2010- & \\
\hline Bank of Ireland Start-up and Emerging Sectors Fund, & \\
2010- & \\
\hline
\end{tabular}




\section{Appendix B. The Comparison of the two Regional Systems}

Table B.1. Comparison of regional systems - the institutional dimension

\begin{tabular}{|c|c|c|}
\hline & Skåne & Southern-Eastern \\
\hline $\begin{array}{l}\text { National policies } \\
\text { before mid-90's }\end{array}$ & $\begin{array}{l}\text { - Proactive science and } \\
\text { technology policy for specific } \\
\text { sectors } \\
\text { - Systemic recognition on the } \\
\text { importance of knowledge } \\
\text { economy } \\
\text { Gradual recognition on the } \\
\text { third role (developmental) of } \\
\text { universities and research } \\
\text { institutions }\end{array}$ & $\begin{array}{l}\text { - Orientation towards Foreign } \\
\text { Direct Investments } \\
\text { need to support indigenous } \\
\text { industry and specific sectors } \\
\text { Formulation of strong } \\
\text { enterprise base around } \\
\text { academic centres business } \\
\text { parks and across the region }\end{array}$ \\
\hline
\end{tabular}




\begin{tabular}{|c|c|c|}
\hline $\begin{array}{l}\text { National policies } \\
\text { since mid-90's }\end{array}$ & $\begin{array}{l}\text { National policies with } \\
\text { adaptation to the regional needs } \\
\text { major institutions and } \\
\text { champions such as LU and } \\
\text { IDEON } \\
\text { - System-oriented } \\
\text { Emphasis on the building of } \\
\text { regionalised diffusion } \\
\text { mechanisms and systemic } \\
\text { relations } \\
\text { Regional governance retains a } \\
\text { - Fery strong presence on } \\
\text { and competitive Research } \\
\text { innovation policy } \\
\text { formulation of the regional } \\
\text { innovation system and } \\
\text { European support programmes } \\
\text { - }\end{array}$ & $\begin{array}{l}\text { - Centrally designed in } \\
\text { national level } \\
\text { - Policy focused on few } \\
\text { - Multi-level but fragmented } \\
\text { with supporting mechanisms } \\
\text { for indigenous and foreign- } \\
\text { owned companies } \\
\text { Recognition of the need for } \\
\text { systemic orientation } \\
\text { Regional governance retains } \\
\text { a limited role on innovation } \\
\text { policy design and } \\
\text { implementation } \\
\text { European Structural Funds }\end{array}$ \\
\hline
\end{tabular}

Source: Appendix D, Table D.1 
Table B2. Sector's major features

\begin{tabular}{|c|c|c|c|c|c|c|c|c|c|c|}
\hline \multicolumn{5}{|c|}{ No of firms in operation by period } & \multicolumn{6}{|c|}{ No of firms in operation after 2006 , by period } \\
\hline \multirow[t]{2}{*}{ Period } & \multicolumn{2}{|c|}{ Total } & \multicolumn{2}{|c|}{ Universities' } & \multicolumn{3}{|c|}{ Origin } & \multicolumn{3}{|c|}{ Size } \\
\hline & Skåne & S-E & Skåne & S-E & & Skåne & S-E & & Skåne & S-E \\
\hline $\begin{array}{l}\text { Before } \\
1990\end{array}$ & 8 & 16 & 4 & 0 & $\begin{array}{l}\text { Universities } \\
\text { \& institutes' }\end{array}$ & 37 & 28 & Micro & 52 & 24 \\
\hline $\begin{array}{l}1991- \\
1995\end{array}$ & 16 & 19 & 5 & 0 & spin-offs & & & Small & 8 & 25 \\
\hline $\begin{array}{l}1996- \\
2000\end{array}$ & 23 & 40 & 4 & 13 & $\begin{array}{l}\text { Large firms } \\
\text { spin-outs }\end{array}$ & 3 & 7 & Medium & 8 & 12 \\
\hline
\end{tabular}




\begin{tabular}{|l|l|l|l|l|l|l|l|l|l|l|}
\hline $2001-$ & 37 & 61 & 6 & 11 & MNE's & 2 & 17 & Large & - & 6 \\
2005 & & & & & & & & & \\
\hline After & 68 & 67 & 18 & 4 & Indigenous & 26 & 15 & & & \\
2006 & & & & & start-ups & & & & \\
\hline
\end{tabular}

Source: Appendix D, Table D.1

Table B3. Segments, business models and source of co-funding

No of firms in operation after 2006, by

\begin{tabular}{|l|l|l|l|l|l|l|l|l|}
\hline \multicolumn{2}{|l|}{} & \multicolumn{3}{c|}{ Business model } & \multicolumn{3}{c|}{ Source of co-funding } \\
\hline & Skåne & S-E & & Skåne & S-E & & Skåne & S-E \\
\hline
\end{tabular}




\begin{tabular}{|c|c|c|c|c|c|c|c|c|}
\hline Bio-pharma & 36 & 25 & $\begin{array}{l}\text { Product } \\
\text { oriented }\end{array}$ & 40 & 42 & $\begin{array}{l}\text { Venture } \\
\text { Capital and/or } \\
\text { supported by } \\
\text { major bio- } \\
\text { pharma firms }\end{array}$ & 56 & 41 \\
\hline Diagnostics & 7 & 8 & $\begin{array}{l}\text { Platforms } \\
\text { (Specialised } \\
\text { Services) }\end{array}$ & 20 & 24 & $\begin{array}{l}\text { Publicly listed } \\
\text { companies }\end{array}$ & 12 & 26 \\
\hline Therapeutics & 8 & 7 & $\begin{array}{l}\text { Therapies/ } \\
\text { treatments }\end{array}$ & 8 & 1 & & & \\
\hline $\begin{array}{l}\text { Bio-analytic } \\
\text { services }\end{array}$ & 3 & 7 & & & & & & \\
\hline Bio-materials & 5 & 8 & & & & & & \\
\hline Bio-food & 4 & 6 & & & & & & \\
\hline Other & 5 & 6 & & & & & & \\
\hline
\end{tabular}

Source: Appendix D, Table D.1 
Table B.4. Regional systems' business environment comparison

\begin{tabular}{|c|c|c|}
\hline & Skåne & Southern Eastern \\
\hline Growth period & $\begin{array}{l}\text { First companies established } \\
\text { in the mid-80s till mid-90s } \\
\text { - Acceleration starts at the } \\
2000 \mathrm{~s}\end{array}$ & $\begin{array}{l}\text { - Most established by late } \\
\text { 1990s, attracted by IDA } \\
\text { initiatives. } \\
\text { - Half of firms are MNEs or } \\
\text { MNEs' spin-outs. }\end{array}$ \\
\hline $\begin{array}{l}\text { Structure of the } \\
\text { sector }\end{array}$ & $\begin{array}{l}\text { - LU spin-offs are the drivers } \\
\text { of activity } \\
\text { - Employment is fragmented } \\
\text { into a large number of micro } \\
\text { \& small firms }\end{array}$ & $\begin{array}{l}\text { - More than } 20 \text { MNEs present } \\
\text { in the region } \\
\text { - MNEs are the drivers of } \\
\text { activity and employment }\end{array}$ \\
\hline Major segments & $\begin{array}{l}\text { - Bio-pharma } \\
\text { - Therapeutics } \\
\text { - Diagnostics }\end{array}$ & $\begin{array}{l}\text { - } \text { Bio-pharma } \\
\text { - } \text { Diagnostics } \\
\text { - Bio-materials } \\
\text { - Bio-analytic services } \\
\text { - Bio-food }\end{array}$ \\
\hline
\end{tabular}




\begin{tabular}{|c|c|c|}
\hline Business models & $\begin{array}{l}\text { - DBF'S mostly oriented to } \\
\text { intermediate biotechnology } \\
\text { products such as active } \\
\text { compounds, ingredients, kits } \\
\text { or proteins } \\
\text { - Specialised research } \\
\text { providers } \\
\text { Firms with emphasis on new } \\
\text { therapies or treatments based } \\
\text { usually on patents. } \\
\text { Internationalisation depends } \\
\text { on Medicon } \\
\text { Valley/Copenhagen-based } \\
\text { firms } \\
\text { Over-reliance on knowledge } \\
\text { depends on public funding }\end{array}$ & $\begin{array}{l}\text { - MNE's oriented to drug } \\
\text { delivery } \\
\text { - DBF's dependence on } \\
\text { MNE's investments, } \\
\text { activities and specialisations } \\
\text { - benefited by MNEs } \\
\text { international supply chains. } \\
\text { Over-reliance on public- } \\
\text { backed VC mechanisms }\end{array}$ \\
\hline $\begin{array}{l}\text { Major ownership } \\
\text { schemes }\end{array}$ & $\begin{array}{l}\text { Multi-partite schemes: } \\
\text { Holding companies with VC } \\
\text { participation }\end{array}$ & $\begin{array}{l}\text { - Publicly Listed Companies } \\
\text { - Publicly backed VC } \\
\text { companies }\end{array}$ \\
\hline
\end{tabular}




\begin{tabular}{|c|c|c|}
\hline Source of finance & $\begin{array}{l}\text { - National and international } \\
\text { private VCs } \\
\text { - Regional public \& EU } \\
\text { supported funding networks } \\
\text { and organisations }\end{array}$ & 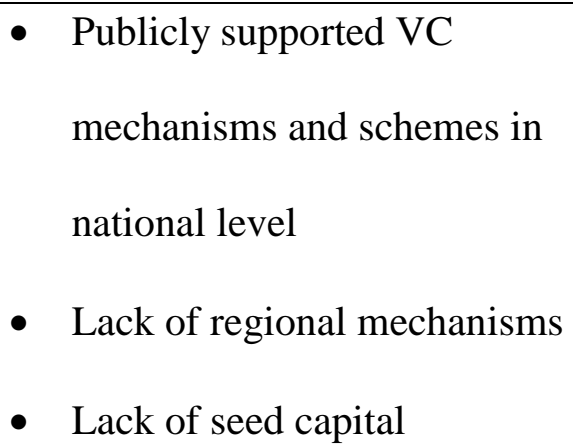 \\
\hline $\begin{array}{l}\text { Strategic } \\
\text { actors/couplings }\end{array}$ & $\begin{array}{l}\text { - } \text { Lund University } \\
\text { - } \quad \text { Medicon Valley }\end{array}$ & - $\quad$ Pharmaceutical MNEs \\
\hline
\end{tabular}

Table B.5. Summary of interviewees' perceptions regarding the innovation policy and structures

\begin{tabular}{|l|l|}
\hline Key perceptions, Skåne & Key perceptions, Southern-Eastern \\
\hline
\end{tabular}


- Radical shift towards innovation system approach since mid 1990s. Emphasis on:

○ public-private collaboration,

O the 'third' role of universities (triple helix model)

- Shift of responsibility for economic development:

○ 'Functional Regions'

○ Regional Agreements

○ National policy actors, such as VINNOVA, direct regional policy \& investment priorities

○ Compliance with the national policy objectives.

- Explicit recognition for the strategic economic importance of life sciences and biotechnology by all the stakeholders central factor to the regional agreements.

- Many active regional networks and 'triple helix' type collaborations, especially in the Medicon Valley area:

- Systemic role of LU in public-private partnerships and developing initiatives for knowledge exploration and exploitation,.
- Gradual evolution to knowledge based economy and innovation systems mentality since late 1990 s.

○ National policy actors are major funding mechanisms and drivers of change at the level of design and implementation;

○ National programmes, e.g. Technology Transfer Initiative, incubation and business supporting mechanisms ignited knowledge transformation activity - limited initial interest and scale of activities.

○ Need of a higher degree of coordination to create economies of scale and scope.

- Regional development based on the EU co-financed Operational Programme, with focus on developing infrastructure:

○ Regional agencies and assembles have partial role on design;

- Fragmented and of limited scale.

- Recognition of the biotechnology sector as a priority for industrial 


\section{Appendix C. Codification of the two distinctive Value Generation Systems}

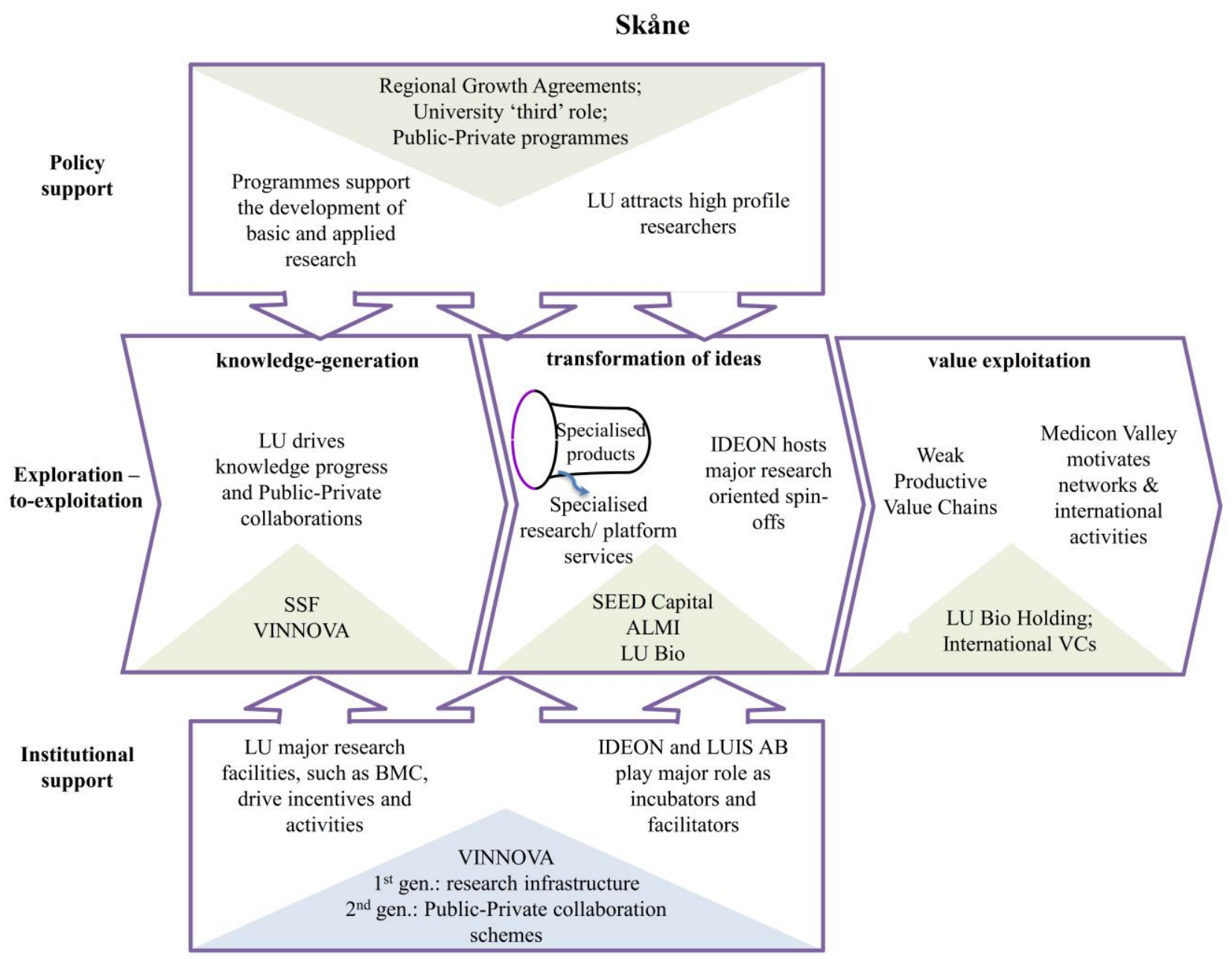

Fig. C.1. The regional value-generation system of Skåne’s biotechnology sector 


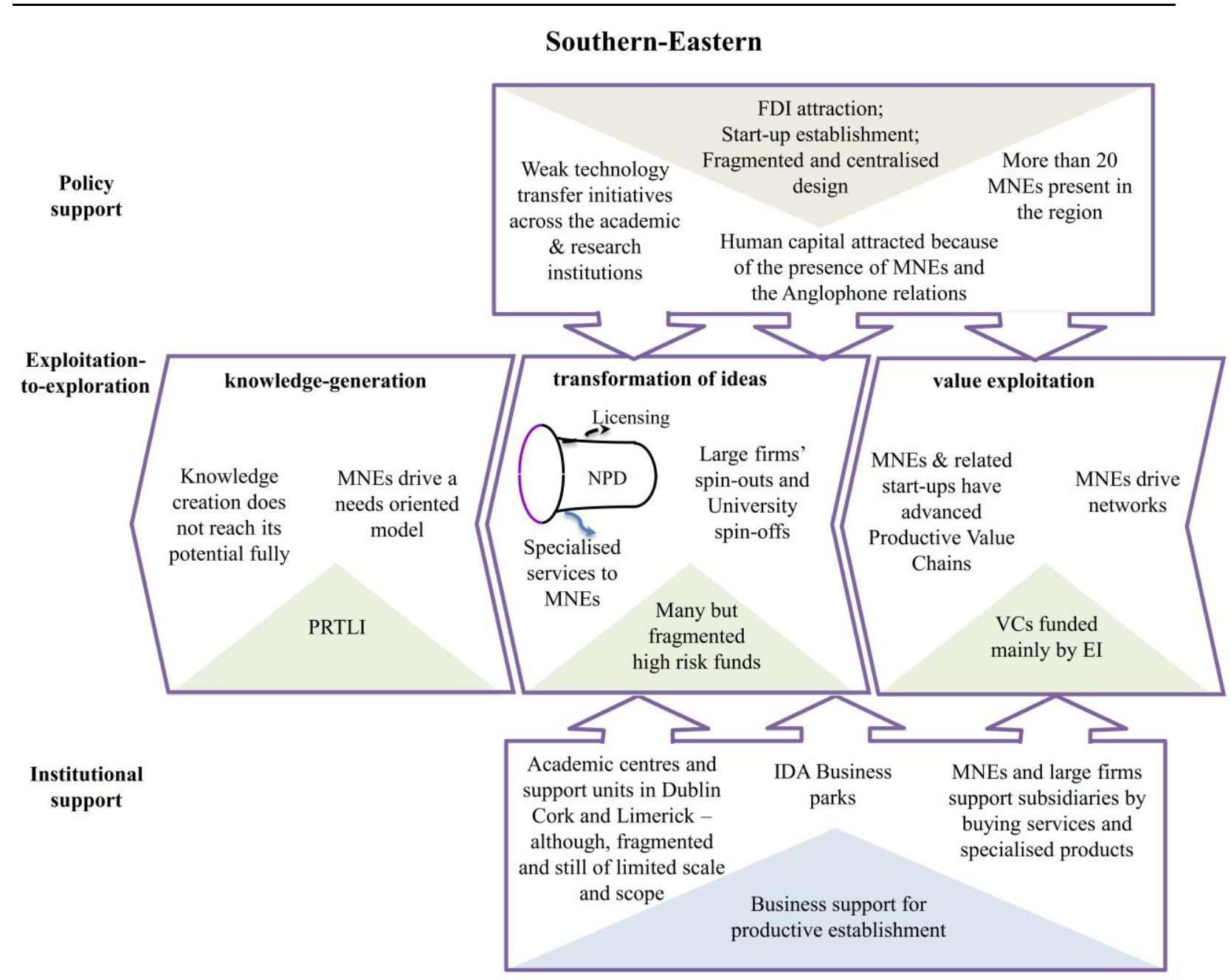

Fig. C.2. The regional value-generation system in Southern-Eastern's biotechnology sector

\section{Appendix D. Data sources - mini reference list}

Table D.1. Sources of information

\begin{tabular}{|l|l|}
\hline Studies & Websites \\
ENTERPRISE IRELAND (2011) Technology Transfer in Ireland & ENTERPRISE IRELAND, https \\
\hline $\begin{array}{l}\text { FISKEN, J. and RUTHERFORD, J. (2002) Business models and } \\
\text { investment trends in the biotechnology industry in Europe, Journal of } \\
\text { Commercial Biotechnology 8, 191-199. }\end{array}$ & FORF/04/2011. \\
\hline
\end{tabular}




\begin{tabular}{|c|c|}
\hline $\begin{array}{l}\text { FORFAS (2000) Enterprise 2010: A New Strategy for the Promotion of } \\
\text { Enterprise in Ireland in the 21st Century, Dublin: Forfás. }\end{array}$ & $\begin{array}{l}\text { INDUSTRIAL DEV } \\
\text { http://www.idaireland.com/, acce }\end{array}$ \\
\hline $\begin{array}{l}\text { FORFAS (2009a) Science, Technology and Innovation: Delivering the } \\
\text { Smart Economy, Dublin. }\end{array}$ & $\begin{array}{l}\text { INVEST IN SKANE, http:// } \\
\text { 12/05/2010. }\end{array}$ \\
\hline $\begin{array}{l}\text { FORFAS (2009b) Health Life Sciences in Ireland - an enterprise } \\
\text { outlook, Dublin. }\end{array}$ & $\begin{array}{l}\text { MEDICON VALLEY, http:/// } \\
\text { 18/04/2011. }\end{array}$ \\
\hline $\begin{array}{l}\text { FORFAS (2011) Analysis of Ireland's Innovation Performance, } \\
\text { Dublin. }\end{array}$ & VINNOVA, http://www.vinnova \\
\hline $\begin{array}{l}\text { LAGNEVIK, M. SJOHOLM, I., LAREKE, A. \& OSTBERG, J. (2003) } \\
\text { The dynamics of innovation clusters: a study of the food industry, New } \\
\text { Horizons in the Economics of Innovation, Cheltenham UK: Edward } \\
\text { Elgar. }\end{array}$ & \\
\hline $\begin{array}{l}\text { OECD (2003) Öresund - Denmark/Sweden, OECD Territorial Reviews, } \\
\text { Paris: OECD. }\end{array}$ & \\
\hline $\begin{array}{l}\text { OECD (2006) The Øresund Science Region: A cross-border } \\
\text { partnership between Denmark and Sweden, Peer Review Report, Paris: } \\
\text { OECD. }\end{array}$ & \\
\hline $\begin{array}{l}\text { VINNOVA (2001) Regional Growth through Dynamic Innovation } \\
\text { Systems, Vinnova. }\end{array}$ & \\
\hline $\begin{array}{l}\text { VINNOVA (2002) Effective innovation systems and problem-oriented } \\
\text { research for sustainable growth VINNOVA's strategic plan 2003-2007, } \\
\text { Stockholm. }\end{array}$ & \\
\hline
\end{tabular}




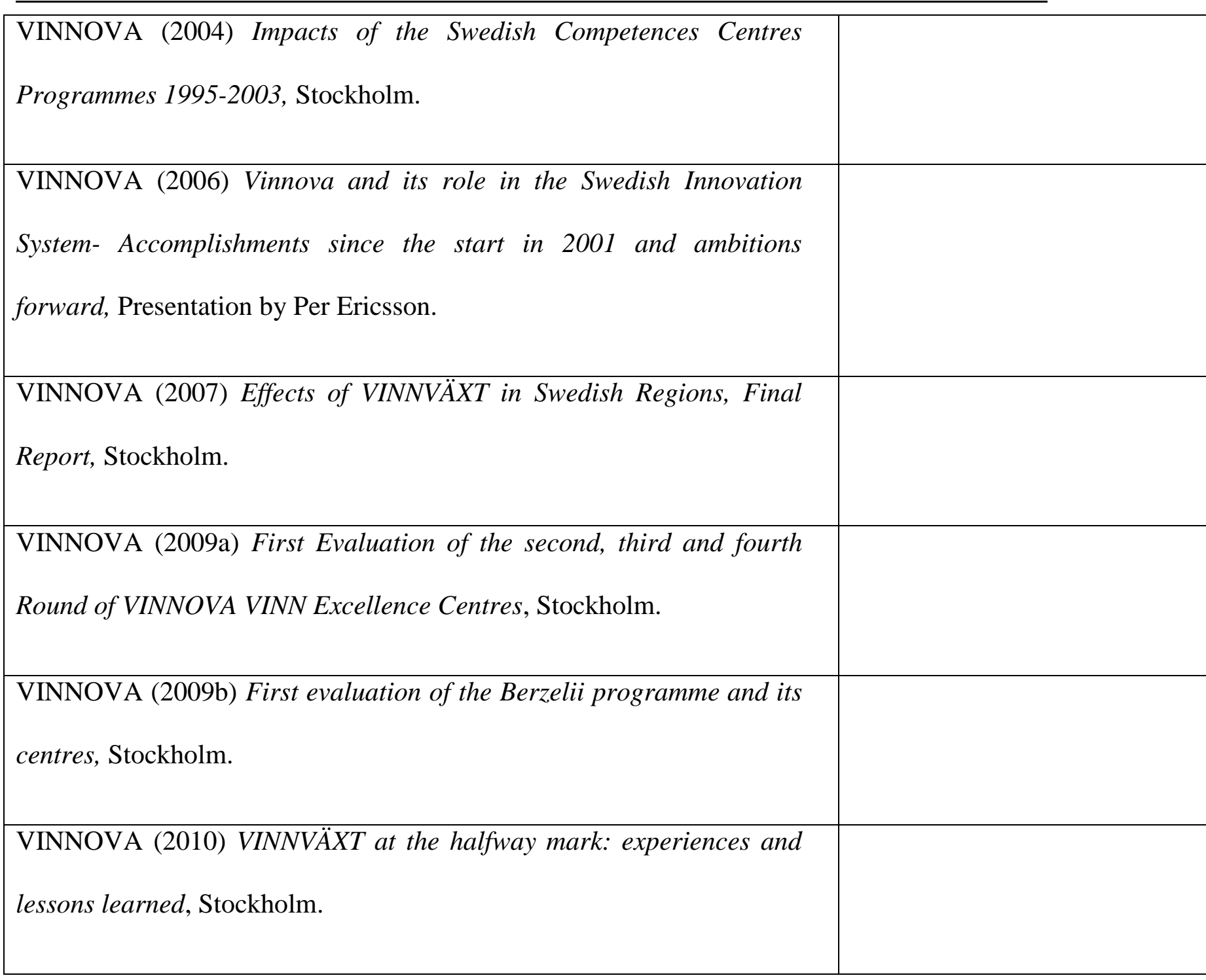

